\title{
Decrease in intracellular superoxide sensitizes Bcl-2-overexpressing tumor cells to receptor and drug-induced apoptosis independent of the mitochondria
}

\author{
M-V Clément ${ }^{1}$, JL Hirpara ${ }^{2}$ and S Pervaiz ${ }^{\star 2}$ \\ ${ }^{1}$ Department of Biochemistry, National University of Singapore, 10 Kent Ridge \\ Crescent, Singapore 119260, Singapore \\ 2 Department of Physiology, National University of Singapore, 2 Medical Drive, \\ MD9 03-06, Singapore 117597, Singapore \\ * Corresponding author: S Pervaiz, Department of Physiology, National \\ University of Singapore, 2 Medical Drive, MD9 \#03-06, Singapore 117597 \\ Singapore. Tel: + 65-6874-6602; Fax: + 65-6778-8161; \\ E-mail: phssp@nus.edu.sg
}

Received 13.11.02; revised 12.5.03; accepted 23.5.03; published online 1 August 2003 Edited by Dr Green

\begin{abstract}
At least two mechanisms of early cytosolic acidification during apoptotic signaling have been described, one that involves caspase 8 activation downstream of receptor ligation and another dependent on mitochondria-derived hydrogen peroxide during merocil-induced apoptosis. Here, we show that Bcl-2 inhibits both mechanisms of acidification. Moreover, Bcl-2 overexpression resulted in a slightly elevated constitutive level of superoxide anion and $\mathrm{pH}$ in CEM leukemia cells. Interestingly, decreasing intracellular superoxide concentration with an inhibitor of the $\beta$-nicotinamide adenine dinucleotide phosphate oxidase or by transient transfection with a dominant-negative form of the guanosine triphosphate-binding protein Rac1 resulted in a significant increase in the sensitivity of CEM/Bcl-2 cells to CD95- or merocil-induced apoptosis. This increase in sensitivity was a direct result of a significant increase in caspase 8 activation and caspase 8-dependent acidification in the absence of caspase 9 activity or cytochrome $c$ release. These findings suggest a mechanism of switching from mitochondriadependent to mitochondria-independent death signaling in the same cell, provided the intracellular milieu is permissive for upstream caspase 8 activation, and could have implications for favorably tailoring tumor cells for drug treatment even when the mitochondrial pathway is compromised by $\mathrm{Bcl}-2$. Cell Death and Differentiation (2003) 10, 1273-1285, doi:10.1038/ s..cdd. 4401302

Published online 1 August 2003
\end{abstract}

Keywords: tumor cells; apoptosis; superoxide; acidification; caspase activation

Abbreviations: DPI, diphenyleneiodonium; Cyt $c$, cytochrome C; BCECF-AM, 2' $7^{\prime}$-bis(2-carboxyethyl)-5,6-carboxyfluorescein; DCFH-DA, 2', $7^{\prime}$-dichlorofluorescein diacetate; $\mathrm{O}_{2}^{-}$, superoxide; $\mathrm{H}_{2} \mathrm{O}_{2}$, hydrogen peroxide

\section{Introduction}

Apoptosis is a genetically programmed death pathway triggered in response to both physiological signals and pathological insults. ${ }^{1}$ The effector components of this execution pathway involve the activation of intracellular caspases and death amplification factors released from the mitochondria, such as cytochrome $c$ (Cyt $c$ ), apoptosis-inducing factor, Smac/Diablo, and caspase proteases. ${ }^{2}$ Whereas some death stimuli induce execution pathways that engage the mitochondria, there are others that function independent of the mitochondria. This phenomenon has been clearly demonstrated in cells triggered to undergo apoptosis through ligation of the cell surface receptor CD95 (Apo-1/Fas). Cells that readily recruit and robustly activate caspase 8 in response to CD95 ligation undergo death execution independent of the mitochondria (Type I pathway) via direct downstream activation of execution caspases. Alternatively, cells that fail to induce early caspase 8 activation strongly upon receptor ligation are dependent upon mitochondria-derived proapoptotic factors to trigger efficient caspase activation for the execution of the death command (Type II pathway). ${ }^{3}$ Overexpression of $\mathrm{Bcl}-2$ prevents the mitochondrial release of proapoptotic factors and therefore inhibits death signaling in Type II cells by blocking caspase activation downstream of the mitochondria.

Despite the clearly established two pathways leading to activation of executioner caspases and cell death, one common event following induction of apoptosis is acidification of the intracellular milieu. ${ }^{4}$ Indeed, a number of recent reports have demonstrated that cytosolic acidification is a permissive environment for the execution of the death signal. ${ }^{5-10}$ At least two mechanism(s) for cytosolic acidification have been described, one that functions downstream of caspase activation and the other that involves mitochondria-derived hydrogen peroxide $\left(\mathrm{H}_{2} \mathrm{O}_{2}\right)$. The former was demonstrated with CD95-mediated apoptosis ${ }^{11}$ and more recently with somatostatin-induced receptor-mediated apoptosis, ${ }^{9}$ and the latter was shown by us during drug-induced apoptosis in HL60 leukemia cells with a novel anticancer agent merocil. ${ }^{8}$ Acidification upon receptor-mediated apoptosis is inhibited by $\mathrm{Bcl}-2 ;{ }^{12,13 ;}$ however, there is no evidence to suggest an inhibitory role for $\mathrm{Bcl}-2$ on $\mathrm{H}_{2} \mathrm{O}_{2}$-mediated cytosolic acidification. Hence, in this report using the Type II leukemia cell line CEM, in which the mitochondrial pathway was shut down by $\mathrm{Bcl}-2$ overexpression (CEM/Bcl-2), we first investigated if in addition to the inhibition of CD95-mediated caspase-dependent acidification, $\mathrm{Bcl}-2$ could also inhibit drug-induced $\mathrm{H}_{2} \mathrm{O}_{2}-$ dependent drop in cytosolic $\mathrm{pH}$. Indeed, we show that $\mathrm{Bcl}-2$ inhibits both caspase (specifically caspase 8 )-dependent as well as $\mathrm{H}_{2} \mathrm{O}_{2}$-dependent cytosolic acidification. Intrigued by these findings, we further questioned whether the death 
inhibitory effect of $\mathrm{Bcl}-2$ was mediated by a decrease in mitochondrial production of $\mathrm{H}_{2} \mathrm{O}_{2}$ on the one hand and the generation of a nonpermissive intracellular milieu for caspase 8 activation on the other. In this regard, our recent observations have highlighted the regulatory role of intracellular superoxide anion $\left(\mathrm{O}_{2}^{-}\right)$and cytosolic acidification on apoptotic signaling in tumor cells. Maintaining a slightly elevated intracellular concentration of $\mathrm{O}_{2}^{-}$inhibited apoptotic signaling, irrespective of the trigger, and conversely a decrease in intracellular $\mathrm{O}_{2}^{-}$resulted in a dramatic increase in the sensitivity of tumor cells to apoptosis by facilitating caspase activation. ${ }^{14-16}$ Therefore, in addition to establishing a link between the death-inhibitory activity of Bcl-2 and its ability to create an environment nonconducive for caspase 8 activation, we investigated if a decrease in intracellular $\mathrm{O}_{2}^{-}$could override or bypass $\mathrm{Bcl}-2$ protection during death signaling, and if this effect was mediated via facilitating caspase 8 activation. Here, we report that a decrease in intracellular $\mathrm{O}_{2}^{-}$, achieved by pharmacological inhibition of the $\beta$-nicotinamide adenine dinucleotide phosphate (NADPH) oxidase complex or by transient transfection with a dominant-negative form of the guanosine triphosphate (GTP)-binding protein Rac1 enhances the sensitivity of $\mathrm{CEM} / \mathrm{Bcl}-2$ cells to apoptosis. This increase in sensitivity to CD95- or merocil-induced apoptosis is mediated by a significant increase in caspase 8 activity and caspase 8-dependent cytosolic acidification and results in the death of $\mathrm{CEM} / \mathrm{Bcl}-2$ cells independent of the mitochondrial pathway. These findings suggest a novel mechanism by which a switch from mitochondria-dependent to mitochondriaindependent death signaling could occur in the same cell, provided the intracellular milieu is permissive for caspase 8dependent acidification, and could have potential implications for favorably tailoring the response of tumor cells to drug treatment even when the mitochondrial death signaling is compromised by overexpression of Bcl-2.

\section{Results}

\section{Bcl-2 blocks caspase and $\mathrm{H}_{2} \mathrm{O}_{2}$-induced cytosolic acidification}

In order to assess the effect of $\mathrm{Bcl}-2$ overexpression on caspase and $\mathrm{H}_{2} \mathrm{O}_{2}$-mediated acidification, CD95 ligation was used as a model for caspase-mediated acidification, ${ }^{11}$ whereas merocil was used as a trigger for the mitochondrial

Figure $1 \mathrm{Bcl}-2$ inhibits drug-induced acidification. (a) Western blot analysis of $\mathrm{Bcl}-2$ expression was performed in $\mathrm{CEM} / \mathrm{Neo}$ and $\mathrm{CEM} / \mathrm{Bcl}-2$ cells using a primary anti-Bcl2 antibody (clone Bcl-2/100; BD Pharmingen, San Diego, CA, USA) as described in Materials and Methods. (b) In all, $1 \times 10^{6} \mathrm{CEM} / \mathrm{Neo}$ and $\mathrm{CEM} / \mathrm{Bcl}-2$ were exposed to $50 \mu \mathrm{g} / \mathrm{ml}$ of merocil for $12 \mathrm{~h}$ and enzymatic activities of caspases 3,8 , and 9 were assessed using specific fluorimetric substrates. Data are shown as fold increase ( $x$ increase in enzymatic activity). $1 \times$ represents the activity in control cells without the apoptotic trigger. (c) Cells were exposed to merocil for $18 \mathrm{~h}$ and apoptosis was assessed by PI staining and shown as sub-G1 (\%). (d) In all, $1 \times 10^{6} \mathrm{CEM} / \mathrm{Neo}$ and CEM/Bcl-2 were exposed to $50 \mu \mathrm{g} \mathrm{ml}$ of merocil in the presence of catalase $(1000 \mathrm{U} / \mathrm{ml})$ or caspase inhibitor (50 $\mu \mathrm{M}$ ZVAD-fmk) for $4 \mathrm{~h}$ (pHi). pHi was measured by using BCECF-AM as described in Materials and Methods. (e) In all, $1 \times 10^{6}$ cells (CEM/Neo or CEM/ $\mathrm{Bcl}-2$ ) were incubated with $50 \mu \mathrm{g} / \mathrm{ml}$ of merocil for $4 \mathrm{~h}$ and intracellular $\mathrm{H}_{2} \mathrm{O}_{2}$ was determined by DCHF-DA staining and analyzed by flow cytometry as described in Materials and Methods generation of $\mathrm{H}_{2} \mathrm{O}_{2}$ and $\mathrm{H}_{2} \mathrm{O}_{2}$-dependent acidification. ${ }^{8}$ The leukemia cell line CEM stably transfected with the empty vector (CEM/Neo) or with $\mathrm{Bcl}-2$ (CEM/Bcl-2) (Figure 1a) was triggered to undergo apoptosis by incubation with $50 \mu \mathrm{g} / \mathrm{ml}$ merocil or $0.25 \mu \mathrm{g} / \mathrm{ml}$ of anti-CD95 (clone $\mathrm{CH} 11$ ). Unlike CEM/ Neo cells, caspase activation (Figure 1b) and apoptosis

a
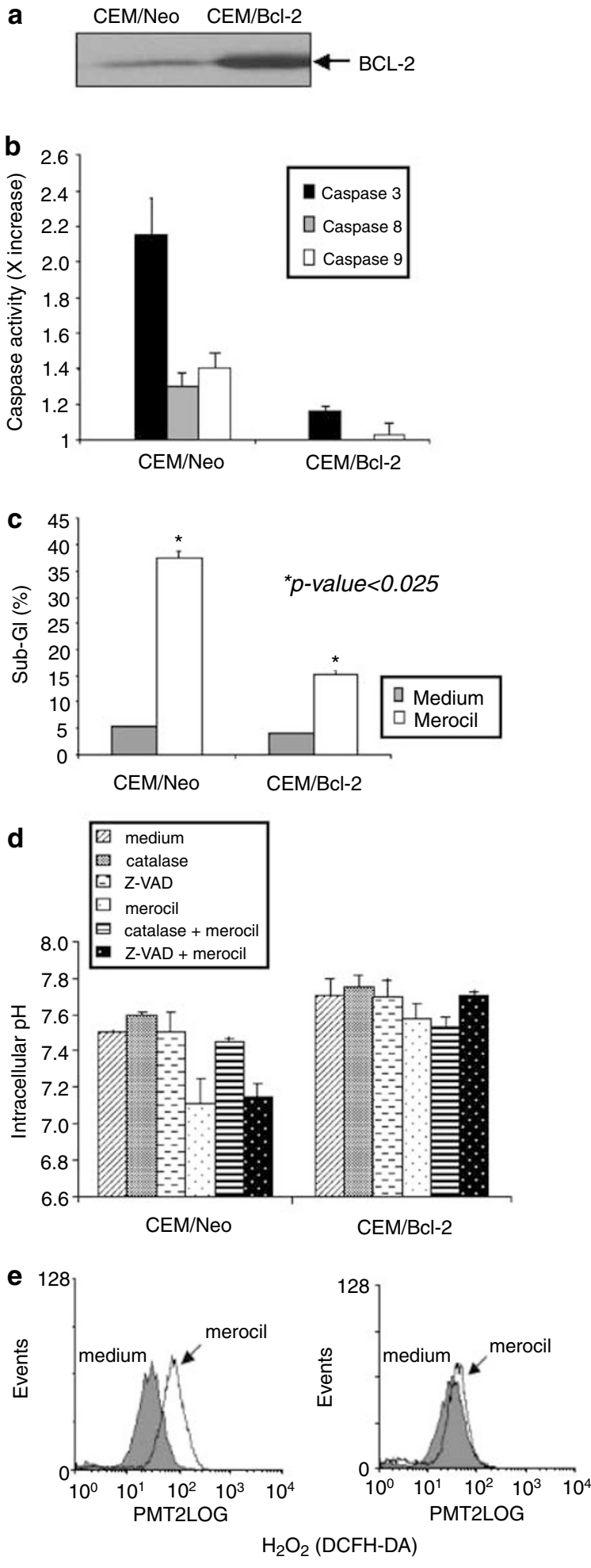
(sub-G1 fraction) were significantly inhibited in CEM/Bcl-2 cells (Figure 1c) upon exposure to merocil. In agreement with the data supporting an early drop in intracellular $\mathrm{pH}(\mathrm{pHi})$ during apoptotic signaling, the $\mathrm{pHi}$ of $\mathrm{CEM} / \mathrm{Neo}$ cells dropped significantly $(\Delta \mathrm{pH}=0.4$ (from 7.5 to 7.1) for merocil or $\Delta \mathrm{pH}=0.3$ for anti-CD95)) within $4 \mathrm{~h}$ of exposure to either apoptotic stimulus as shown in Figures $1 \mathrm{~d}$ and $2 \mathrm{a}$. Moreover, as shown previously with HL60 cells, $^{8}$ merocil-induced acidification occurred independent of caspase activation (no effect of the general caspase inhibitor ZVAD-fmk), but was completely inhibited by preincubation with the $\mathrm{H}_{2} \mathrm{O}_{2}$ scavenger catalase (Figure 1d). On the contrary, preincubation of $\mathrm{CEM} / \mathrm{Neo}$ cells with catalase had no effect on cytosolic acidification triggered by ligation of the CD95 death receptor (Figure 2a). However, CD95-induced acidification was downstream of caspase activation as evidenced by the inhibitory effect of the general caspase inhibitor ZVAD-fmk (data not shown). Furthermore, similar to the results obtained with somatostatin, ${ }^{9}$ our results showed that the specific caspase involved in the induction of acidification during CD95 ligation was caspase 8, as caspase 8-specific inhibitor LETD-fmk completely inhibited the drop in pHi (Figure 2a); inhibitors of caspase 3 (DEVD-fmk) or caspase 9 (LEHD-fmk) did not significantly prevent CD95-induced cytosolic acidification (data not shown). These findings confirm the existence of distinct mechanism(s) for cytosolic acidification in response to receptor- and drug-induced apoptosis. ${ }^{8,13,17}$ Interestingly, overexpression of $\mathrm{Bcl}-2$ resulted in the inhibition of both $\mathrm{H}_{2} \mathrm{O}_{2}$ and caspase-mediated acidification (Figures $1 \mathrm{~d}$ and 2a). These data, together with our observation that $\mathrm{Bcl}-2$ inhibited $\mathrm{H}_{2} \mathrm{O}_{2}$ production upon merocil-induced apoptosis (Figure 1e), corroborate our recent findings demonstrating the role of mitochondrial $\mathrm{H}_{2} \mathrm{O}_{2}$ in merocil-induced cytosolic acidification. ${ }^{8}$ In this study and in our previous work, we used the probe $2^{\prime}, 7^{\prime}$-dichlorofluorescein diacetate (DCFH-DA) for the flow cytometric detection of intracellular $\mathrm{H}_{2} \mathrm{O}_{2}$. Although it has recently been suggested that the presence of Cyt $c$ could cast doubt vis-à-vis the specificity of DCFH-DA, two observations presented here clearly demonstrate that in our system the change in fluorescence was indeed a measure of intracellular $\mathrm{H}_{2} \mathrm{O}_{2}$. First, we did not detect any Cyt $c$ release at the time of detection of $\mathrm{H}_{2} \mathrm{O}_{2}$ (by DCFH-DA) in CEM/Neo cells incubated with merocil and second, Cyt $c$ release upon CD95 ligation of $\mathrm{CEM} / \mathrm{Neo}$ cells occurred without any

Figure 2 Bcl-2 inhibits CD95-induced acidification. (a) In all, $1 \times 10^{6} \mathrm{CEM} / \mathrm{NeO}$ and CEM/Bcl-2 were exposed to $0.25 \mu \mathrm{g} / \mathrm{ml}$ of anti-CD95 for $4 \mathrm{~h}(\mathrm{pHi})$ in the presence or absence of catalase $(1000 \mathrm{U} / \mathrm{ml})$ or caspase 8 inhibitor $(50 \mu \mathrm{M}$ LETD-fmk). pHi was measured by using BCECF-AM as described in Materials and Methods. (b) A total of $2 \times 10^{6} \mathrm{CEM} / \mathrm{Neo}$ or $\mathrm{CEM} / \mathrm{Bcl}-2$ cells were incubated with $0.25 \mu \mathrm{g} / \mathrm{ml}$ of anti-CD95 for 4 or $8 \mathrm{~h}$ and capase 8 activity was determined in lysates using a fluorimetric assay with caspase 8-specific substrate as described in Materials and Methods. Results are shown as fold increase ( $x$ increase) in enzyme activity over the untreated control cells $(1 \times)$. Data are means \pm S.D. of at least three independent experiments. (c) Lysates obtained from $5 \times 10^{6}$ cells (CEM/Neo and CEM/Bcl-2) following incubation with $0.25 \mu \mathrm{g} / \mathrm{ml}$ of anti-CD95 for $12 \mathrm{~h}$ were subjected to Western blot analysis for Bid cleavage using a polyclonal anti-Bid that recognizes the full-length Bid or an antibody that picks up the t-Bid as described in Materials and Methods. (d) Apoptosis was assessed following incubation of cells with anti-CD95 for $18 \mathrm{~h}$ by PI staining and data are shown as sub-G1\% dichlorofluorescein (DCF) fluorescence, as these cells did not produce intracellular $\mathrm{H}_{2} \mathrm{O}_{2}$ (data not shown).

\section{Decrease in intracellular $\mathrm{O}_{2}^{-}$restores caspase 8 activity and acidification upon CD95-induced apoptosis in CEM/Bcl-2 cells}

The inhibitory effect of $\mathrm{Bcl}-2$ on mitochondrial generation of $\mathrm{H}_{2} \mathrm{O}_{2}$ as shown here with merocil is rather easily argued as
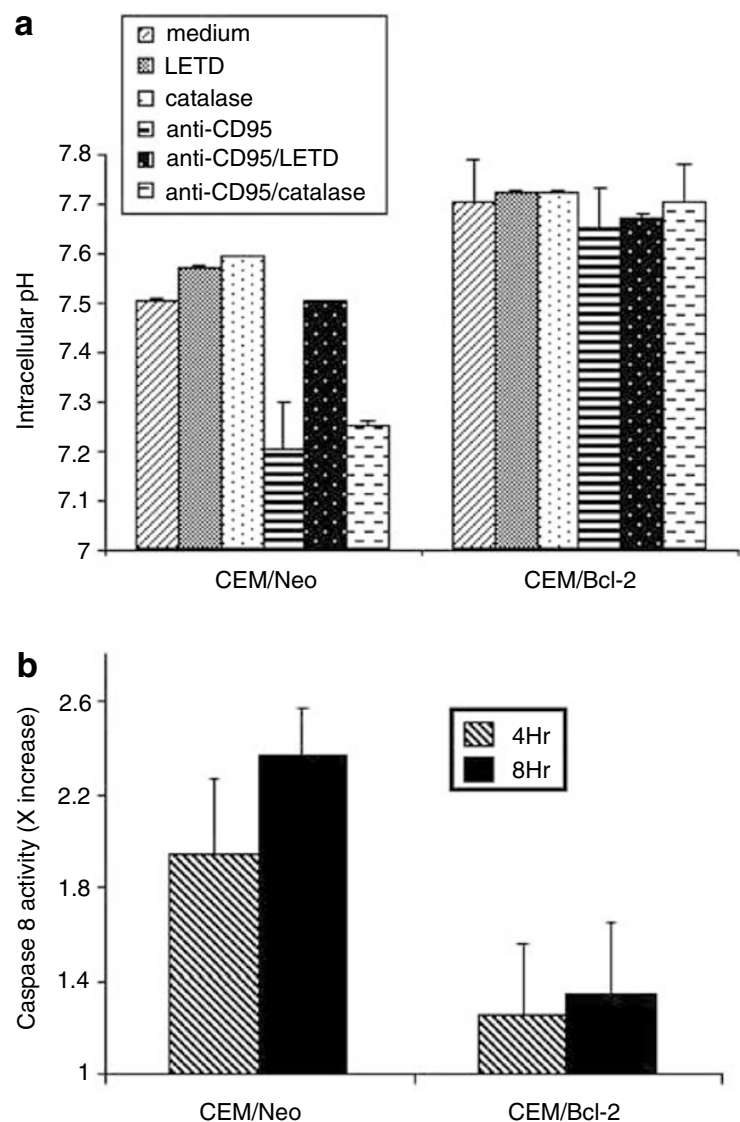

C
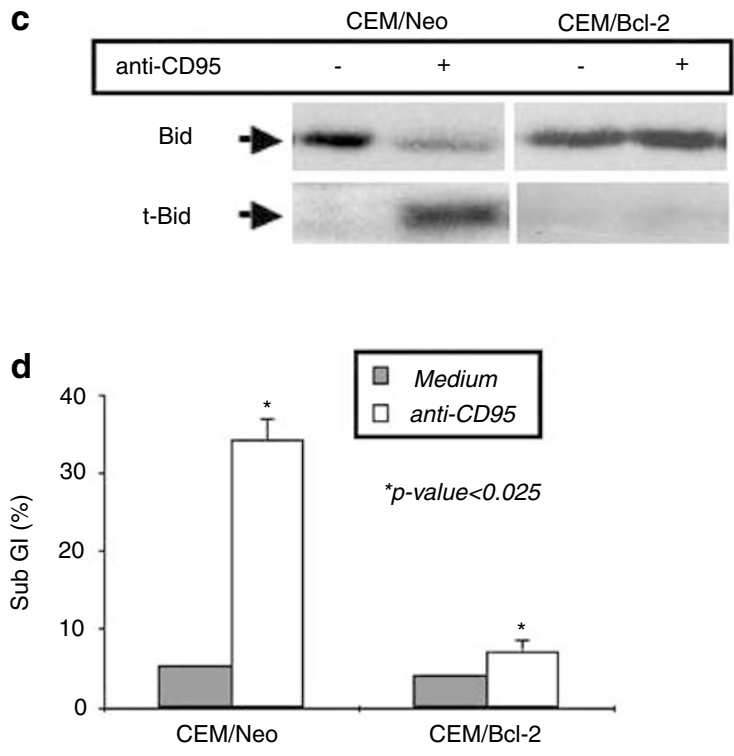
this would lead to not only an inhibition of cytosolic acidification but also block apoptotic signaling downstream of the mitochondria. This could also explain the inhibition of caspase 8 activity in CEM/Bcl-2 cells upon exposure to merocil (data not shown) as unlike receptor-induced caspase 8 activation, recent evidence places drug-induced caspase 8 activity downstream of the mitochondria. ${ }^{18,19}$ Earlier reports with CD95-induced apoptosis also argue in favor of a mechanism of caspase 8 activation downstream of the mitochondria in Type II cells, and hence the ability of $\mathrm{Bcl}-2$ to block caspase 8 activation in this system. ${ }^{3}$ As receptorinduced cytosolic acidification has been attributed to early caspase 8 activation, ${ }^{9}$ the inhibition of CD95-induced cytosolic acidification in CEM/Bcl-2 cells suggests a role for $\mathrm{Bcl}-2$ in inhibiting a step upstream of caspase 8 activation and acidification. Indeed, caspase 8 activity upon CD95-induced apoptosis is significantly inhibited in CEM/Bcl-2 cells (Figure $2 \mathrm{~b}$ ), which is accompanied by inhibition of proteolytic cleavage of the proapoptotic Bcl-2 protein Bid, a substrate of caspase 8 (Figure 2c), and as expected, ligation of the CD95 receptor significantly $(P$-value $<0.025)$ blocked apoptotic death (sub-G1 fraction) in CEM/Bcl-2 cells (Figure $2 \mathrm{~d}$ ). In light of these data, we argue that the inhibition of CD95-mediated apoptosis by $\mathrm{Bcl}-2$ could be due to an intracellular environment (of $\mathrm{CEM} / \mathrm{Bcl}-2$ cells) nonconducive for the activation or activity of caspase 8.

Interestingly, $\mathrm{Bcl}-2$ expression has been linked to a change in the redox status of the cell, with reports linking its antioxidant activity to an indirect effect on the cells' antioxidant defenses by creating a slightly pro-oxidant intracellular milieu. ${ }^{20-22}$ Indeed, our results showing an increase in the steady-state levels of intracellular $\mathrm{O}_{2}^{-}$in the stably transfected $\mathrm{CEM} / \mathrm{Bcl}-2$ cells, compared to the CEM/Neo cells (Figure 3 ), provide impetus to this hypothesis and is in line with our published reports that an increase in steady-state levels of intracellular $\mathrm{O}_{2}^{-}$inhibits apoptosis triggered via CD95 ligation, ${ }^{16}$ and contrarily a decrease in intracellular $\mathrm{O}_{2}^{-}$enhances the sensitivity of tumor cells to a variety of apoptotic triggers. ${ }^{14-16,23}$ In order to confirm a role for the higher steady-state intracellular concentration of $\mathrm{O}_{2}^{-}$of $\mathrm{CEM} / \mathrm{Bcl}-2$

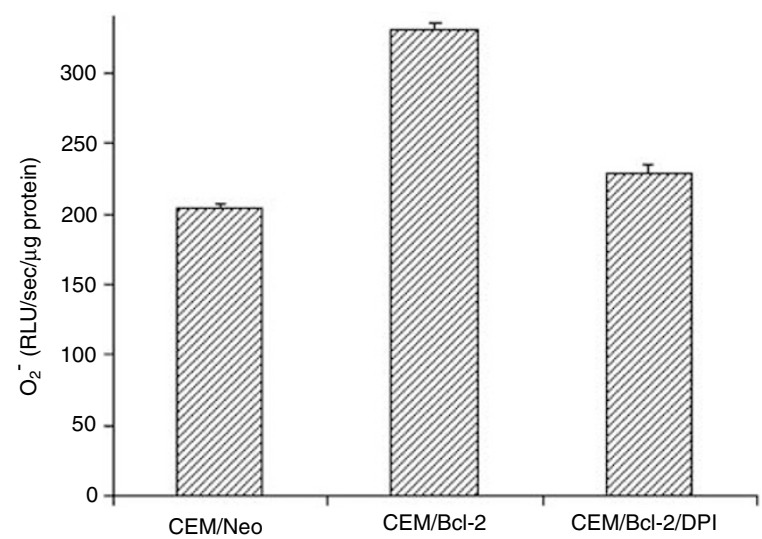

Figure 3 DPI decreases intracellular $\mathrm{O}_{2}^{-}$in $\mathrm{CEM} / \mathrm{Bcl}-2$ cells. Steady-state levels of intracellular $\mathrm{O}_{2}^{-}$were determined in $1 \times 10^{6} \mathrm{CEM} / \mathrm{NeO}$ or CEM/Bcl-2 or $\mathrm{CEM} / \mathrm{Bcl}-2$ cells treated for $1 \mathrm{~h}$ with $2.5 \mu \mathrm{M}$ DPI (CEM/Bcl-2/DPI) by the lucigenin-based chemiluminescence assay described in Materials and Methods. Means \pm S.D. of three independent measurements are shown cells in the inhibition of caspase 8-mediated acidification upon CD95 triggering, we investigated whether a decrease in intracellular $\mathrm{O}_{2}^{-}$could restore caspase 8 activity and cytosolic acidification upon CD95 ligation. In order to accomplish this, we exploited the NADPH oxidase blocking activity of the widely used inhibitor diphenyleneiodonium (DPI) to decrease intracellular concentration of $\mathrm{O}_{2}^{-} .^{16}$ Incubation of $\mathrm{CEM} / \mathrm{Bcl}-2$ cells with $2.5 \mu \mathrm{M}$ DPI for $2 \mathrm{~h}$ (CEM/Bcl-2/DPI) resulted in a significant decrease in intracellular $\mathrm{O}_{2}^{-}$as compared to the CEM/Bcl-2 cells (Figure 3). CEM/Bcl-2 and CEM/Bcl-2/DPI cells were then triggered to undergo apoptosis by incubation with $0.25 \mu \mathrm{g} / \mathrm{ml}$ of anti-CD95, followed by measurements of $\mathrm{pHi}(4 \mathrm{~h})$, caspase 8 and 3 activities (4-8h), and cell death (18h). Unlike CEM/Bcl-2 cells (Figure 2a), CEM/Bcl-2/DPI cells underwent cytosolic acidification $(\Delta \mathrm{pH}=0.4)$ as shown in Figure 4a, significant increases in caspases 8 and 3 activities (Figure 4b), cleavage of the caspase 8 substrate Bid (Figure $4 \mathrm{c}$ ), and cell death (47 versus $3 \%$ in $\mathrm{CEM} / \mathrm{Bcl}-2$ cells) upon CD95 ligation (Figure 4b). In addition, consistent with the role of caspase 8 in cytosolic acidification, blocking caspase 8 activity (50 $\mu \mathrm{M}$ LETD-fmk) inhibited cytosolic acidification in response to anti-CD95 in CEM/Bcl-2/DPI cells (Figure 4a). Similar to the results obtained in CEM/Neo cells, inhibitors of caspase 3 (DEVD-fmk) or caspase 9 (LEHD-fmk) did not significantly prevent CD95-induced cytosolic acidification in CEM/Bcl-2/DPI cells (data not shown).

\section{CD95-mediated apoptosis in CEM/Bcl-2/DPI cells is independent of Cyt $c$ release and caspase 9 activity}

There could be two possible explanations for the sensitivity of CEM/Bcl-2/DPI cells to CD95-mediated apoptosis. One simple argument could be that the inhibitory activity of $\mathrm{Bcl}-2$ was compromised ${ }^{24}$ and that the increase in caspase 8 activity observed upon preincubation with DPI was simply a function of breakdown of mitochondrial protective effect of $\mathrm{Bcl}-2$, thereby restoring mitochondrial death signaling in these cells. An alternative and more intriguing possibility could be that $\mathrm{CEM} / \mathrm{Bcl}-2 / \mathrm{DPI}$ cells are using a mitochondria-independent pathway for caspase activation and cell death. Our results showed that despite the increase in the overall sensitivity of CEM/Bcl-2/DPI cells to cell death, there was no detectable Cyt $c$ release in $\mathrm{CEM} / \mathrm{Bcl}-2 / \mathrm{DPI}$ cells upon incubation with anti-CD95 as compared to the CEM/Neo cells (Figure 5a). Consistent with our data shown in Figure $4 \mathrm{~b}$, the sensitivity of CEM/Bcl-2/DPI cells to CD95 receptor-induced cell death was significantly increased $(P$-value $<0.05)$ than that of the CEM/Bcl-2 cells (Figure $5 \mathrm{~b}$ ). In addition, unlike caspase 8 inhibitor (LETD-fmk), preincubation of cells with the caspase 9 inhibitor (LEHD-fmk) had no effect on the increased sensitivity of CEM/Bcl-2/DPI cells to CD95-mediated apoptosis (Figure $5 b$ ). This is in stark contrast to the CEM/Neo cells, where both inhibitors were equally effective in rescuing cells from anti-CD95-induced cell death (Figure 5b). In order to confirm the complete absence of mitochondrial involvement in the increased sensitivity of CEM/Bcl-2/DPI cells to anti-CD95 treatment, we also assessed the change in the mitochondrial transmembrane potential $\left(\Delta \psi_{m}\right)$. Indeed, we show that the 
a
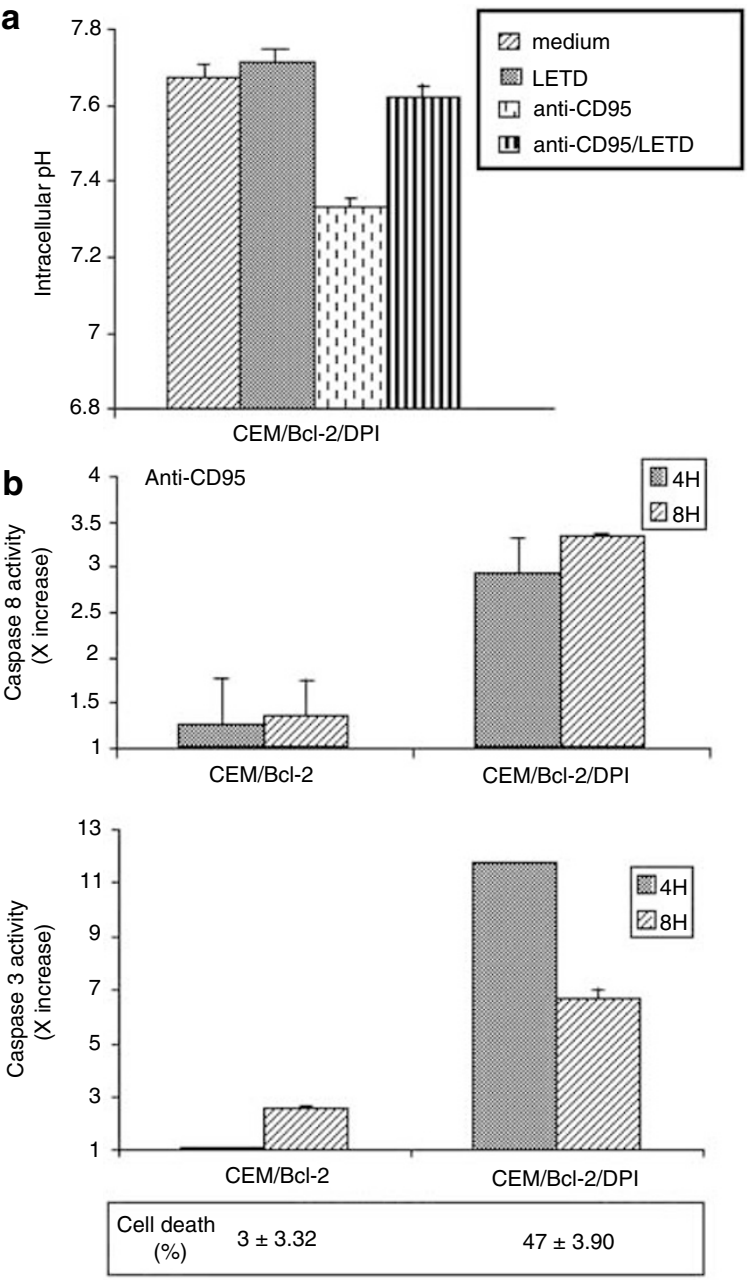

C

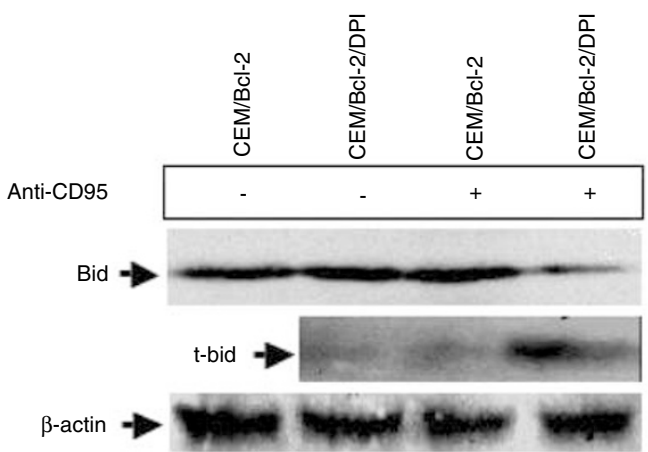

Figure 4 Decrease in intracellular $\mathrm{O}_{2}^{-}$facilitates cytosolic acidification via increased caspase 8 activity. (a) CEM/Bcl2/DPI cells $\left(1 \times 10^{6}\right)$ were treated with $0.25 \mu \mathrm{g} / \mathrm{ml}$ of anti-CD95 in the presence or absence of caspase 8 inhibitor LETDfmk $(50 \mu \mathrm{M})$ for $4 \mathrm{~h}$ and $\mathrm{pHi}$ was measured as described in Materials and Methods. Data shown are means \pm S.D. of three independent experiments. (b) Sensitivity to apoptosis is enhanced in CEM/Bcl-2/DPI cells. $2 \times 10^{6} \mathrm{CEM} / \mathrm{Bcl}-2$ or CEM/Bcl-2/DPI cells were treated with $0.25 \mu \mathrm{g} / \mathrm{ml}$ of anti-CD95 for 4 or $8 \mathrm{~h}$ and caspases 8 and 3 activities were determined in lysates using fluorimetric assays with caspase 8- or 3-specific substrates as described in Materials and Methods. Results are shown as fold increase ( $x$ increase) in enzyme activities over the untreated control cells $(1 \times)$. Cell death was determined by the MTT assay following incubation with anti-CD95. Data are means \pm S.D. of at least three independent experiments. (c) Bid cleavage in lysates from CEM/Bcl-2 and CEM/ Bcl-2/DPI cells following exposure to anti-CD95 $(0.25 \mu \mathrm{g} / \mathrm{ml}$ for $12 \mathrm{~h})$ was detected by Western blotting as described in Materials and Methods. Membrane was probed with anti- $\beta$ actin as an internal control for equal loading a

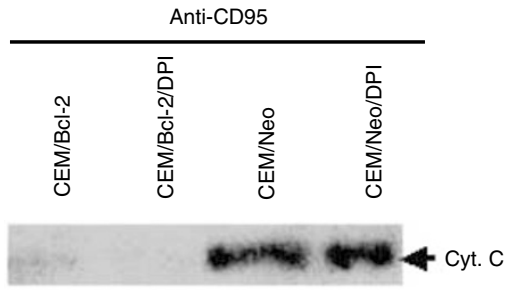

b
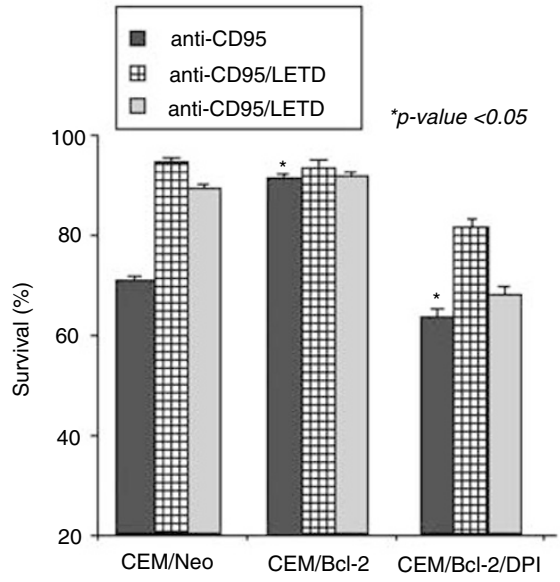

C $52 \% \quad \mathrm{CEM} / \mathrm{Bcl}-2 \quad 87.3 \% \quad 35 \% \quad \mathrm{CEM} / \mathrm{Bcl}-2 / \mathrm{DPI} \quad 54.2 \%$

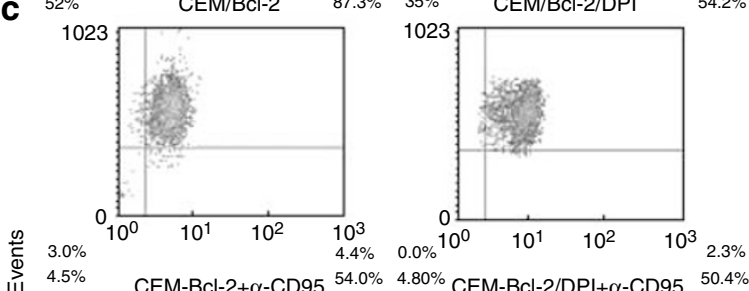

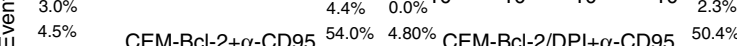

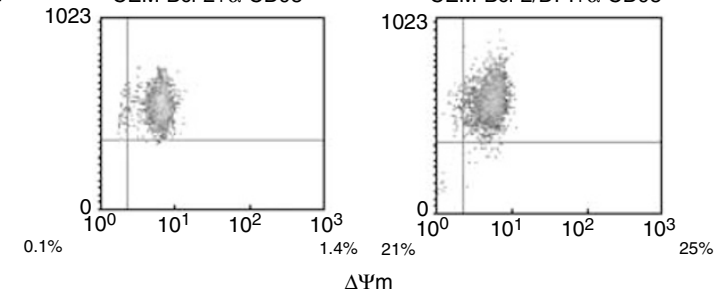

Figure 5 Decrease in intracellular $\mathrm{O}_{2}^{-}$bypasses $\mathrm{Bcl}-2$ protection. (a) Absence of Cyt $c$ release in CEM/Bcl-2/DPI cells upon anti-CD95-induced apoptosis. Release of Cyt $c$ was determined by Western blotting with anti-Cyt $c$ in cytoslic extracts of $20 \times 10^{6}$ cells following exposure to $0.25 \mu \mathrm{g} / \mathrm{ml}$ anti-CD95 for $6 \mathrm{~h}$ as described in Materials and Methods. (b) Increased sensitivity of CEM/Bcl-2/DPI cells to apoptosis is independent of caspase 9 activity. A total of $1 \times 10^{6} \mathrm{CEM} /$ $\mathrm{Bcl}-2$ or CEM/Bcl-2/DPI or CEM/Neo cells were exposed to $0.25 \mu \mathrm{g} / \mathrm{ml}$ of anti$\mathrm{CD} 95$ for $18 \mathrm{~h}$ in the presence or absence of either caspase 8 inhibitor $(50 \mu \mathrm{M}$ LETD-fmk) or caspase 9 inhibitor ( $50 \mu \mathrm{M}$ LEHD-fmk) and cell viability was determined by the MTT assay as described elsewhere. ${ }^{35}$ Data shown are means \pm S.D. of at least three independent experiments. (c) Mitochondrial $\Delta \psi_{\mathrm{m}}$ was measured in CEM/Bcl-2 or CEM/Bcl-2/DPI cells after $6 \mathrm{~h}$ incubation with anti$\operatorname{CD} 95(0.25 \mu \mathrm{g} / \mathrm{ml})$ followed by loading with the fluorescent probe DiOC $_{6}(40 \mathrm{nM})$ and analyzed by flow cytometry. At least 20000 events were analyzed by WinMDI software

increase in sensitivity of CEM/Bcl-2/DPI cells to anti-CD95 exposure was not accompanied by a change in the $\Delta \psi_{\mathrm{m}}$ (Figure $5 c$ ), further providing evidence that the mitochondrial pathway was not involved in this death signaling. It is therefore plausible that the small percentage of cells that underwent 
apoptosis in CEM/Bcl-2 cells could be due to mitochondrialindependent activation of effector caspases. Our results indicate that the increase in sensitivity of CEM/Bcl-2/DPI cells ( $47 \%$ cell death) over the $\mathrm{CEM} / \mathrm{Bcl}-2$ cells ( $<5 \%$ cell death) to receptor-induced apoptosis is due to an increase in caspase 8 activity and caspase 8-dependent cytosolic acidification, which drives the death signal in the absence of Cyt $c$ release and caspase 9 activity. These findings suggest a switch from mitochondria-dependent to mitochondria-independent death signaling in the same cell.

\section{Merocil-induced apoptosis in CEM/Bcl-2/DPI cells is also independent of the mitochondrial pathway}

Interestingly, similar to anti-CD95-induced apoptosis, exposure of $\mathrm{CEM} / \mathrm{Bcl}-2 / \mathrm{DPI}$ cells to merocil also resulted in significantly increased activities of caspases 8 and 3 (but not caspase 9) and cell death (59\% in CEM/Bcl-2/DPI cells versus $18 \%$ in $\mathrm{CEM} / \mathrm{Bcl}-2$ cells) as shown in Figure $6 \mathrm{a}$. However, despite the fact that CEM/Bcl-2/DPI cells acidified upon exposure to merocil $(\Delta \mathrm{pH}=0.47)$, the mechanism of cytosolic acidification did not involve $\mathrm{H}_{2} \mathrm{O}_{2}$ production as preincubation with catalase had no effect on the drop in cytosolic $\mathrm{pH}$ (Figure 6b). Interestingly, and unlike CEM/Neo cells (shown in Figure 1d), merocil-induced acidification upon decreasing intracellular $\mathrm{O}_{2}^{-}$(CEM/Bcl-2/DPI cells) was inhibited by blocking caspase 8 activation (Figure $6 \mathrm{~b}$ ). The fact that this decrease in cytosolic acidification was independent of intracellular $\mathrm{H}_{2} \mathrm{O}_{2}$ production was further corroborated by our results demonstrating the complete absence of an intracellular increase in $\mathrm{H}_{2} \mathrm{O}_{2}$ production (similar to $\mathrm{CEM} / \mathrm{Bcl}-2$ cells) in merocil-treated CEM/Bcl-2/DPI cells (Figure 6c). These results indicate that the inhibitory effect of $\mathrm{Bcl}-2$ on merocilinduced intracellular production of $\mathrm{H}_{2} \mathrm{O}_{2}$ was not compromised in CEM/Bcl-2/DPI cells, and support our data on CD95induced apoptosis that the mitochondrial protective effect of $\mathrm{Bcl}-2$ was not over-ridden in CEM/Bcl-2/DPI cells. Moreover, similar to CD95-mediated apoptosis (Figure $5 \mathrm{~b}$ ), preincubation of cells with the caspase 9 inhibitor (LEHD-fmk) had no

Figure 6 Decrease in intracellular $\mathrm{O}_{2}^{-}$sensitizes $\mathrm{CEM} / \mathrm{Bcl} 2$ cells to merocilinduced apoptosis via increased caspase 8 activation. (a) A total of $2 \times 10^{6} \mathrm{CEM} /$ $\mathrm{Bcl}-2$ or CEM/Bcl-2/DPI cells were treated with $50 \mu \mathrm{g} / \mathrm{ml}$ of merocil for 4 or $8 \mathrm{~h}$ and enzymatic activities of caspases 8,9 , and 3 were determined in lysates using a fluorescent assay with a caspase 8-, 9-, or 3-specific substrate as described in Materials and Methods. Results are shown as fold increase ( $x$ increase) in enzyme activities over the untreated control cells $(1 \times)$. Cell death was determined by the MTT assay following $18 \mathrm{~h}$ incubation with merocil. Data are means \pm S.D. of at least three independent experiments. (b) CEM/Bcl2/DPI cells $\left(1 \times 10^{6}\right)$ were treated with $50 \mu \mathrm{g} / \mathrm{ml}$ of merocil in the presence or absence of caspase 8 inhibitor LETD-fmk $(50 \mu \mathrm{M})$ for $4 \mathrm{~h}$ and $\mathrm{pHi}$ was measured as described in Materials and Methods. Data shown are means \pm S.D. of three independent experiments. (c) A total of $1 \times 10^{6} \mathrm{CEM} / \mathrm{Bcl}-2$ or $\mathrm{CEM} / \mathrm{Bcl}-2 / \mathrm{DPI}$ cells were incubated with $50 \mu \mathrm{g} / \mathrm{ml}$ of merocil for $4 \mathrm{~h}$ and intracellular $\mathrm{H}_{2} \mathrm{O}_{2}$ was determined by DCHF-DA staining and analyzed by flow cytometry as described in Materials and Methods. (d) A total of $1 \times 10^{6} \mathrm{CEM} / \mathrm{Bcl}-2$ or $\mathrm{CEM} / \mathrm{Bcl}-2 / \mathrm{DPI}$ or $\mathrm{CEM} / \mathrm{Neo}$ cells were exposed to $50 \mu \mathrm{g} / \mathrm{ml}$ of merocil for $18 \mathrm{~h}$ in the presence or absence of either caspase 8 inhibitor ( $50 \mu \mathrm{M}$ LETD-fmk) or caspase 9 inhibitor $(50 \mu \mathrm{M}$ LEHD-fmk) and cell viability was determined by the MTT assay as described in Materials and Methods. Data shown are means \pm S.D. of at least three independent experiments
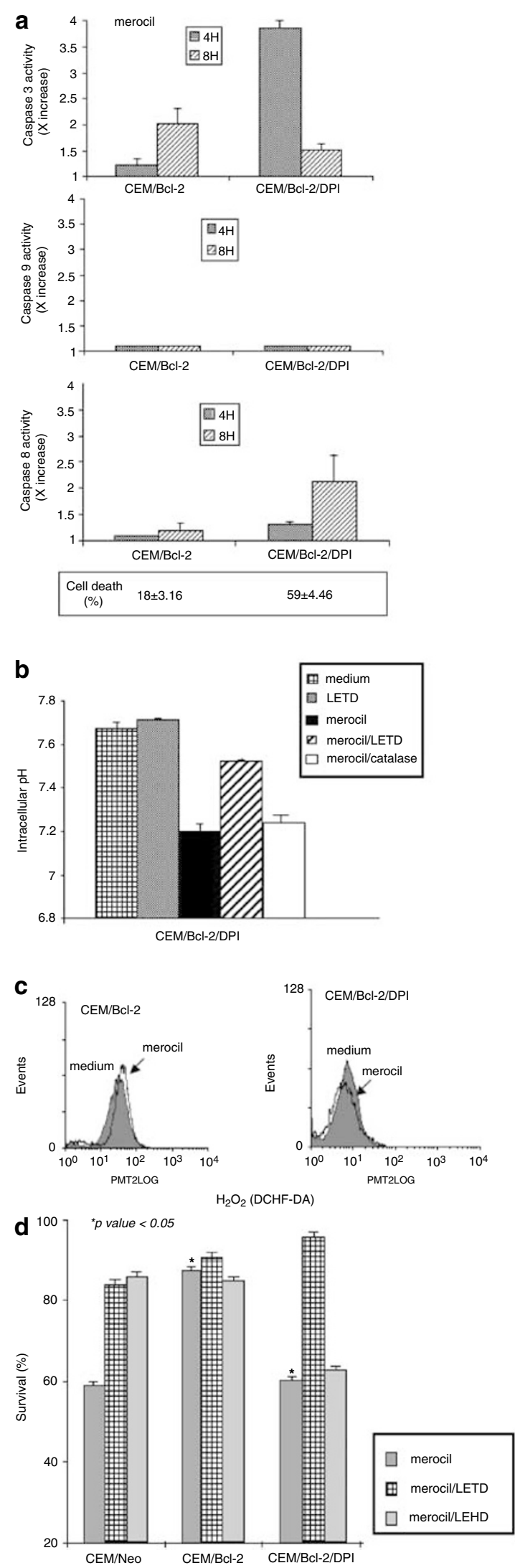
effect on cell sensitivity to merocil-mediated apoptosis in $\mathrm{CEM} / \mathrm{Bcl}-2 / \mathrm{DPI}$, while a significant inhibition was detected in CEM/Neo cells (Figure 6d). Finally, as with anti-CD95induced apoptosis, there was a significant increase in the sensitivity $(P$-value $<0.05)$ of $\mathrm{CEM} / \mathrm{Bcl}-2 / \mathrm{DPI}$ cells to merocilinduced cell death over the $\mathrm{CEM} / \mathrm{Bcl}-2$ cells (Figure $6 \mathrm{~d}$ ). These data demonstrate that a decrease in intracellular $\mathrm{O}_{2}^{-}$ bypasses resistance to apoptosis conferred by $\mathrm{Bcl}-2$ overexpression by facilitating caspase 8-dependent cytosolic acidification independent of the trigger (anti-CD95 or merocil), and are strongly suggestive of a diversion from mitochondriadependent pathway to mitochondria-independent death signaling in the same cell line.

\section{Transient expression of RacN17, a dominant- negative form of the small GTP-binding protein Rac1 in CEM/Bcl-2 cells diverts CD95- and merocil- mediated apoptosis from mitochondria dependent to mitochondria independent}

Metabolic pathways leading to the generation of ROS are best characterized in phagocytic cells. In these cells, $\mathrm{O}_{2}^{-}$is generated by the NADPH oxidase complex. ${ }^{25,26}$ In nonphagocytic cells including tumor cells, the proteins responsible for producing $\mathrm{O}_{2}^{-}$and other ROS are less well defined, but could well function in a manner similar to the phagocyte NADPHoxidase complex. Indeed, it has recently been shown that similar to the phagocyte oxidant-generating system, the production of ROS in nonphagocytic cells is regulated by the small GTP-binding protein Rac1. ${ }^{27-30}$ To this effect, we recently demonstrated that the expression of a constitutively activated form of Rac1 leads to an increase in intracellular $\mathrm{O}_{2}^{-}$ and inhibition of the apoptotic pathway in M14 human melanoma cell line. Conversely, inhibition of Rac1 activation by a dominant-negative mutant of Rac1 (RacN17) resulted in a significant increase in the sensitivity of melanoma cells to apoptosis. ${ }^{14}$ RacN17-mediated increase in tumor cell sensitivity to apoptosis was directly linked to a decrease in

Figure 7 Expression of a dominant-negative form of Rac 1 enhances sensitivity of CEM/Bcl-2 cells independent of the mitochondria. (a) Transient transfection of CEM/Bcl-2 cells with either the empty pIRES vector or pIRESRacN17 was performed as described in Materials and Methods. At 48 hours post transfection, the expression of transiently expressed RacN17 protein was detected by Western blotting as described in Materials and Methods. Intracellular $\mathrm{O}_{2}^{-}$was measured in lysates of $1 \times 10^{6}$ cells by the lucigenein-based chemiluminescence assay and is shown as RLU/s/g protein. (b) $\mathrm{CEM} / \mathrm{Bcl}-2 / \mathrm{plRES}$ or $\mathrm{CEM} / \mathrm{Bcl}-2 /$ RacN17 cells $\left(1 \times 10^{6}\right)$ were exposed to $50 \mu \mathrm{g} / \mathrm{ml}$ of merocil or $0.25 \mu \mathrm{g} / \mathrm{ml}$ of anti-CD95 for $4 \mathrm{~h}$ in the presence or absence of caspase 8 inhibitor $(50 \mu \mathrm{M}$ LETD-fmk) and pHi was measured by BCECF as described in Materials and Methods. (c) Increased sensitivity of CEM/Bcl-2/RacN17 cells to apoptosis is inhibited by blocking caspase 8 activity. Cells were treated as in (b) and survival was assessed $18 \mathrm{~h}$ after incubation with either anti-CD95 or merocil by the $\beta$-gal survival assay described in Material and Methods. (d) Increased sensitivity of CEM/Bcl-2/RacN17 cells to merocil or anti-CD95 is independent of caspase 9 activity. CEM/Neo/plRES or CEM/Bcl-2/RacN17 cells were treated with meroci $(50 \mu \mathrm{g} / \mathrm{ml})$ or anti-CD95 $(0.25 \mu \mathrm{g} / \mathrm{ml})$ in the presence or absence of caspase 9 specific inhibitor ( $50 \mu \mathrm{M}$ LEHD-fmk). Survival was assessed $18 \mathrm{~h}$ following incubation with anti-CD95 or merocil by the $\beta$-gal survival assay described Material and Methods. All data shown are mean \pm S.D. of at least three independent experiments intracellular $\mathrm{O}_{2}^{-}$. Therefore, in order to provide a physiological basis for the data presented with DPI and to dispel any doubts vis-à-vis the use of a chemical, we questioned if similar to our results with DPI, transfection of CEM/Bcl-2 cells with RacN17 could lead to caspase 8-dependent cytosolic acidification upon CD95 ligation or merocil treatment. Indeed, the expression of RacN17 in CEM/Bcl-2 cells (CEM/Bcl-2/ RacN17; Figure 7a) resulted in a significant decrease in the intracellular concentration of $\mathrm{O}_{2}^{-}$as compared to the cells transfected with the vector alone (CEM/Bcl-2/pIRES)

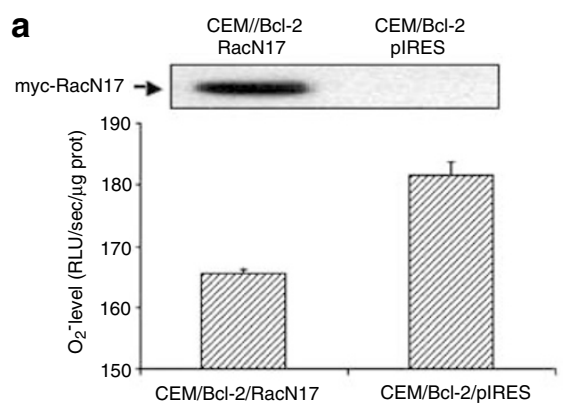

b

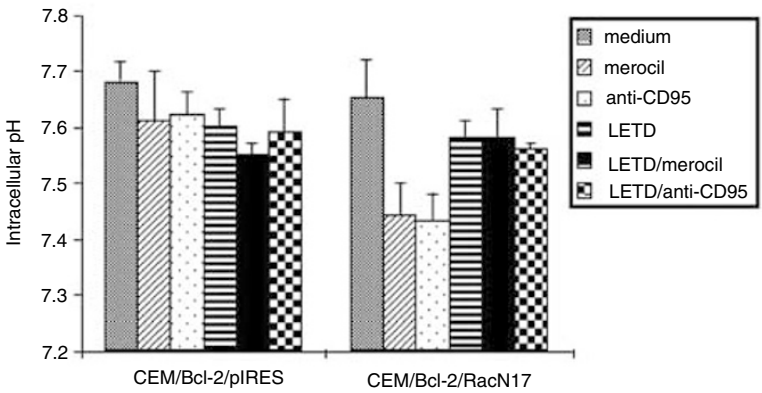

C

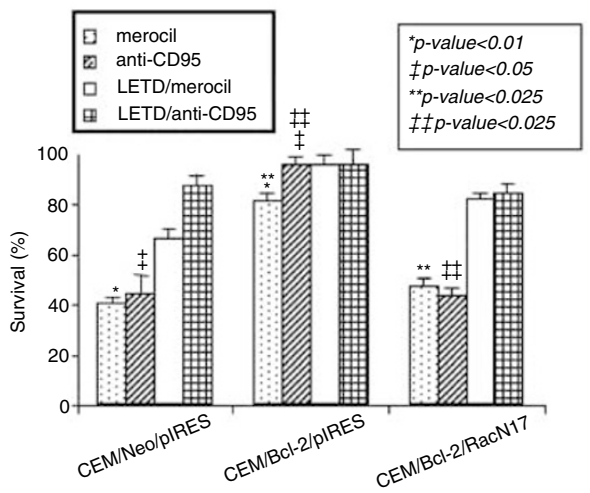

d

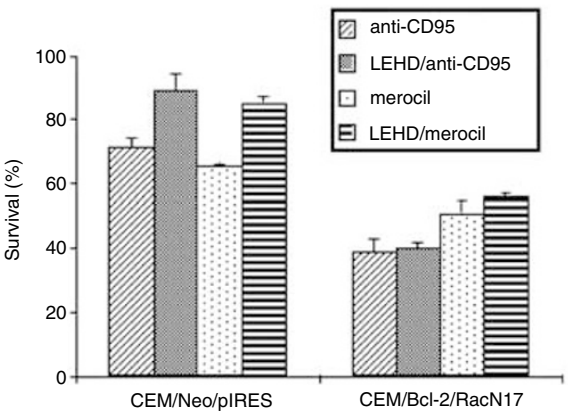


(Figure 7a). In addition, whereas CEM/Bcl-2/pIRES cells did not undergo cytosolic acidification in response to either CD95 ligation or merocil treatment, CEM/Bcl-2/RacN17 cells facilitated cytosolic acidification following induction of apoptosis that was significantly inhibited by the caspase 8 tetrapeptide inhibitor (Figure 7b). It has to be pointed out that the decrease in intracellular $\mathrm{O}_{2}^{-}(11 \%)$ and $\Delta \mathrm{pH}(-0.2)$ obtained upon transient transfection with $\mathrm{RacN} 17$ was the result of measurements performed in the total cell population in which routinely $35-40 \%$ of the cells were transfected. Hence, the changes observed in $\mathrm{O}_{2}^{-}$and $\mathrm{pH}$ were understandably lower than those obtained upon DPI treatment of CEM/Bcl-2 cells (32\% and -0.4 , respectively). In addition, the sensitivity to receptor- or drug-induced apoptosis was increased $(P$-value $<0.025)$ in CEM/Bcl-2/RacN17 cells (compared to CEM/Bcl-2/pIRES cells), which could be reversed upon blocking caspase 8 activation as shown in Figure 7c. It should be pointed out that transfection with the empty vector pIRES did not affect the ability of Bcl-2 to inhibit death signaling as shown by the relative insensitivity of $\mathrm{CEM} / \mathrm{Bcl}-2 /$ pIRES cells to merocil $\left({ }^{*} P\right.$-value $\left.<0.01\right)$ or anti-CD95 $\left({ }^{\ddagger} P\right.$-value $\left.<0.05\right)$ treatment, compared to the CEM/Neo/PIRES cells (Figure 7c). Furthermore, similar to the absence of mitochondrial involvement in the enhanced sensitivity of CEM/Bcl-2/DPI cells in receptoror drug-induced apoptosis, there was no Cyt $c$ release (data not shown), and blocking caspase 9 activity with the LEHDfmk tetrapeptide did not inhibit apoptosis in CEM/Bcl-2/ RacN17 cells, unlike CEM/Neo/pIRES cells (Figure 7d). In these experiments, survival of CEM/Bcl-2/pIRES, CEM/Bcl-2/ RacN17, and CEM/Neo/pIRES cells was assessed by the $\beta$-galactosidase ( $\beta$-Gal) survival assay that allows for the specific measurement of survival of pIRES- or pIRESRacN17transfected cells ${ }^{14}$ (see Materials and Methods). These results further consolidate our finding that the increase in apoptotic sensitivity of $\mathrm{CEM} / \mathrm{Bcl}-2$ cells in a reduced intracellular $\mathrm{O}_{2}^{-}$milieu is not due to compromise of the mitochondrial protective ability of $\mathrm{Bcl}-2$, but indeed due to the induction of caspase-dependent cytosolic acidification and activation of the caspase cascade, independent of the mitochondria.

Finally, to link the increase in sensitivity observed upon transfection with RacN17 (CEM/Bcl-2/RacN17 cells) to a drop in intracellular $\mathrm{O}_{2}^{-}$, we used a pharmacological inhibitor of $\mathrm{Cu} / \mathrm{Zn}$ superoxide dismutase, diethyldithiocarbamate (DDC), ${ }^{14,16}$ to maintain increased intracellular steady-state levels of $\mathrm{O}_{2}^{-}$prior to triggering apoptosis with anti-CD95 (Table 1). Our results showed that preincubation with DDC completely inhibited the drop in cytosolic $\mathrm{pH}$ observed upon

Table 1 Incubation with DDC maintains steady-state increase in intracellular $\mathrm{O}_{2}^{-}$levels in CEM/Bcl-2/pIRES and CEM/Bcl-2/RacN17 cells

\begin{tabular}{lcc}
\hline Cells & Medium & DDC \\
\hline CEM/Bcl-2/ & $181.5 \pm 2.12$ & $677.5 \pm 7.77$ \\
plRES & $165.5 \pm 0.7$ & $619 \pm 12.72$ \\
CEM/Bcl-2/ & & \\
RacN17 & &
\end{tabular}

Cells $\left(1 \times 10^{6}\right)$ were exposed to $500 \mu \mathrm{M} \mathrm{DDC}$ for $4 \mathrm{~h}$ and intracellular $\mathrm{O}_{2}^{-}$was determined by a lucigenin-based chemiluminescence assay as described in Materials and Methods. Data shown are $\mathrm{RLU} / \mathrm{s} / \mu \mathrm{g}$ of protein and are means \pm S.D. of three independent experiments ligation of the CD95 receptor in CEM/Bcl-2/RacN17 cells (Figure 8a). Furthermore, the increase in sensitivity of the cells to anti-CD95 treatment obtained in CEM/Bcl-2/RacN17 cells was also reverted by DDC exposure (Figure $8 \mathrm{~b}$ ). These data provide further support to our findings that the increase in sensitivity to apoptosis observed upon RacN17 transfection was linked to intracellular $\mathrm{O}_{2}^{-}$concentration.

\section{Transient transfection with $\mathrm{Bcl}-2$ increases intracellular $\mathrm{O}_{2}^{-}$and $\mathrm{pH}$ and decreases cell sensitivity to apoptosis}

In order to provide further evidence that the increase in intracellular $\mathrm{O}_{2}^{-}$and cytosolic $\mathrm{pH}$ was linked to $\mathrm{Bcl}-2$ expression, and that elevated level observed in the CEM cells stably transfected with $\mathrm{Bcl}-2$ (CEM/Bcl-2) was not a coincidental finding, we transiently transfected CEM cells with a vector containing $\mathrm{Bcl}-2$ (pcDNA3-Bcl-2). At $48 \mathrm{~h}$ posttransfection, the intracellular levels of $\mathrm{O}_{2}^{-}$, cytosolic $\mathrm{pH}$, and sensitivity to anti-CD95- and drug-induced apoptosis were assessed. Indeed, our results showed that transient transfection of $\mathrm{Bcl}-2$ resulted in significant increases in the constitutive
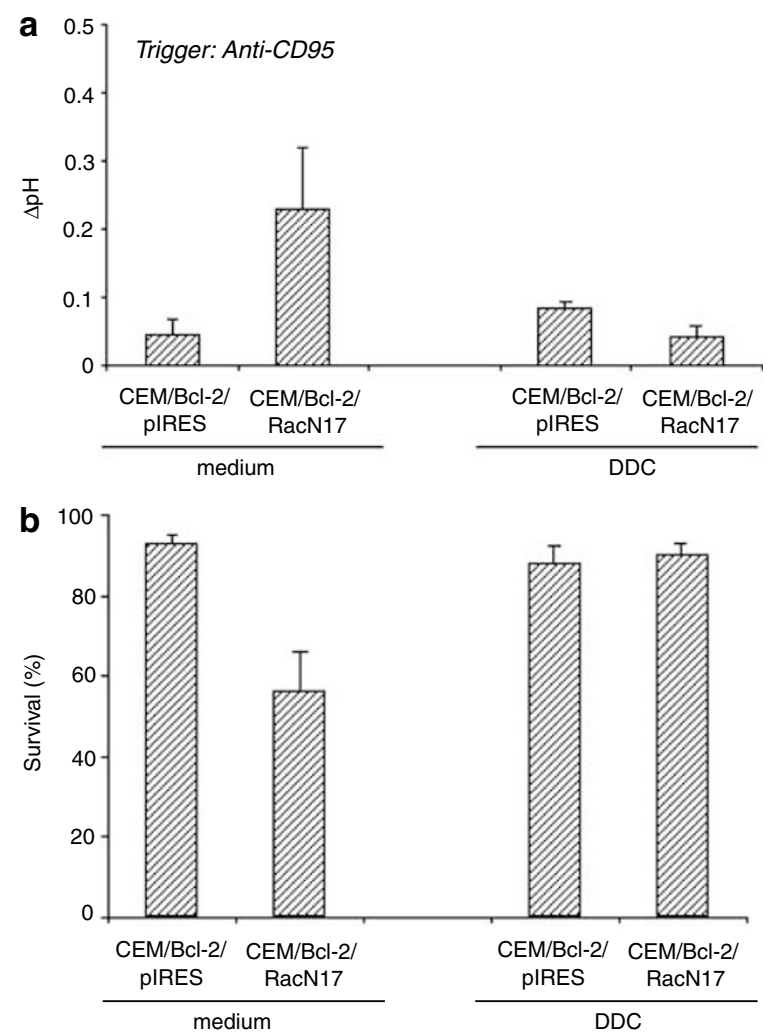

Figure 8 Maintaining increased intracellular concentration of $\mathrm{O}_{2}^{-}$prevents the drop in $\mathrm{pHi}$ and the increase in sensitivity of CEM/Bcl-2/RacN17 cells to antiCD95 treatment. CEM/Bcl-2 cells transiently transfected with either the empty pIRES vector (CEM/Bcl-2/pIRES) or pIRES RacN17 (CEM/Bcl-2/RacN17) were exposed to $500 \mu \mathrm{M} \mathrm{DDC}$ for $1 \mathrm{~h}$ prior to incubation with anti-CD95 $(0.25 \mu \mathrm{g} / \mathrm{ml})$ for $4 \mathrm{~h}$ for measurement of $\mathrm{pHi}$ (a) or $18 \mathrm{~h}$ for determination of cell survival (b). $\mathrm{pHi}$ was measured by loading with BCECF-AM and is shown as the change in $\mathrm{pH}$ $(\Delta \mathrm{pH})$ and cell survival was determined by the $\beta$-Gal survival assay, as described in Materials and Methods. Data shown are means \pm S.D. of three independent observations 
level of intracellular $\mathrm{O}_{2}^{-}$(Figure 9a) and cytosolic $\mathrm{pH}$ (Figure 9b). Whereas cells transfected with the empty vector (CEM/vector) underwent cytosolic acidification upon receptor or drug-induced apoptosis, cells transiently transfected with $\mathrm{Bcl}-2$ (pcDNA3-Bcl-2) resisted the drop in $\mathrm{pH}$ triggered by anti-CD95 or merocil (Figure 9b). In addition, and as expected, the sensitivity of pcDNA3-Bcl-2 cells was significantly decreased to apoptosis triggered either by ligation of the CD95 receptor or by exposure to merocil (Figure 9c). The absence of a complete inhibition of $\mathrm{pH}$ and cell death upon transfection with $\mathrm{Bcl}-2$ could be attributed to the transfection efficiency of $35-40 \%$ routinely obtained in these cells. These data corroborate our findings with the stably transfected CEM cells used in this study, and suggest that Bcl-2 overexpression results in an increase in the intracellular constitutive level of $\mathrm{O}_{2}^{-}$that could, in part, be responsible for the death-inhibiting activity of Bcl-2.

\section{Discussion}

The functional characterization of apoptotic signaling into mitochondria dependent or mitochondria independent is basically derived from the inhibitory effect of $\mathrm{Bcl}-2$ on the former, but not the latter. Irrespective of the nature of the death signaling circuitry, there is a growing body of evidence to suggest that an early drop in cytosolic $\mathrm{pH}$ precedes apoptotic execution. Indeed, a number of recent reports have demonstrated that cytosolic acidification is a permissive environment for the execution of the death signal. ${ }^{5-10}$ At least two mechanism(s) for the drop in pHi following apoptotic triggering have been described, one that functions downstream of caspase activation ${ }^{9,11}$ and the other that involves mitochondria-derived $\mathrm{H}_{2} \mathrm{O}_{2}{ }^{8}$ Whereas acidification upon receptor-mediated apoptosis has been directly linked to upstream caspase 8 activation and is inhibited by overexpression of $\mathrm{Bcl}-2,{ }^{9,12,13}$ we recently demonstrated the direct involvement of mitochondrial $\mathrm{H}_{2} \mathrm{O}_{2}$ in the early drop of cytosolic $\mathrm{pH}$ during merocil-induced apoptosis in HL60 leukemia cells. The present results confirm the involvement of caspase 8 in CD95 signaling-induced acidification in CEM leukemia cells, which is blocked upon overexpression of $\mathrm{Bcl}-2$ (Figure 2). In addition, similar to our results obtained with HL60 cells, merocil-induced cytosolic acidification in CEM cells was blocked by $\mathrm{H}_{2} \mathrm{O}_{2}$ scavenger catalase or the membrane-permeable catalase mimetic EUK-8 (data not shown), but not by the caspase inhibitors (Figures 1 and 2). These data were corroborated by experimental evidence demonstrating a significant intracellular increase in $\mathrm{H}_{2} \mathrm{O}_{2}$ production in CEM cells treated with merocil (Figure 1). Interestingly, we also present data to demonstrate that overexpression of $\mathrm{Bcl}-2$ inhibits both $\mathrm{CD} 95$ receptor-induced acidification, as well as $\mathrm{H}_{2} \mathrm{O}_{2}$-mediated cytosolic acidification triggered upon exposure to the anticancer agent merocil.

The ability of $\mathrm{Bcl}-2$ to inhibit merocil-induced $\mathrm{H}_{2} \mathrm{O}_{2}$ production from the mitochondria supports the inhibitory effect of $\mathrm{Bcl}-$ 2 on mitochondrial ROS generation, which could be linked to the well-documented mitochondrial protective activity of Bcl-2, such as inhibition of peroxide-mediated damage to mitochondrial membranes that allows the egress of proapoptotic
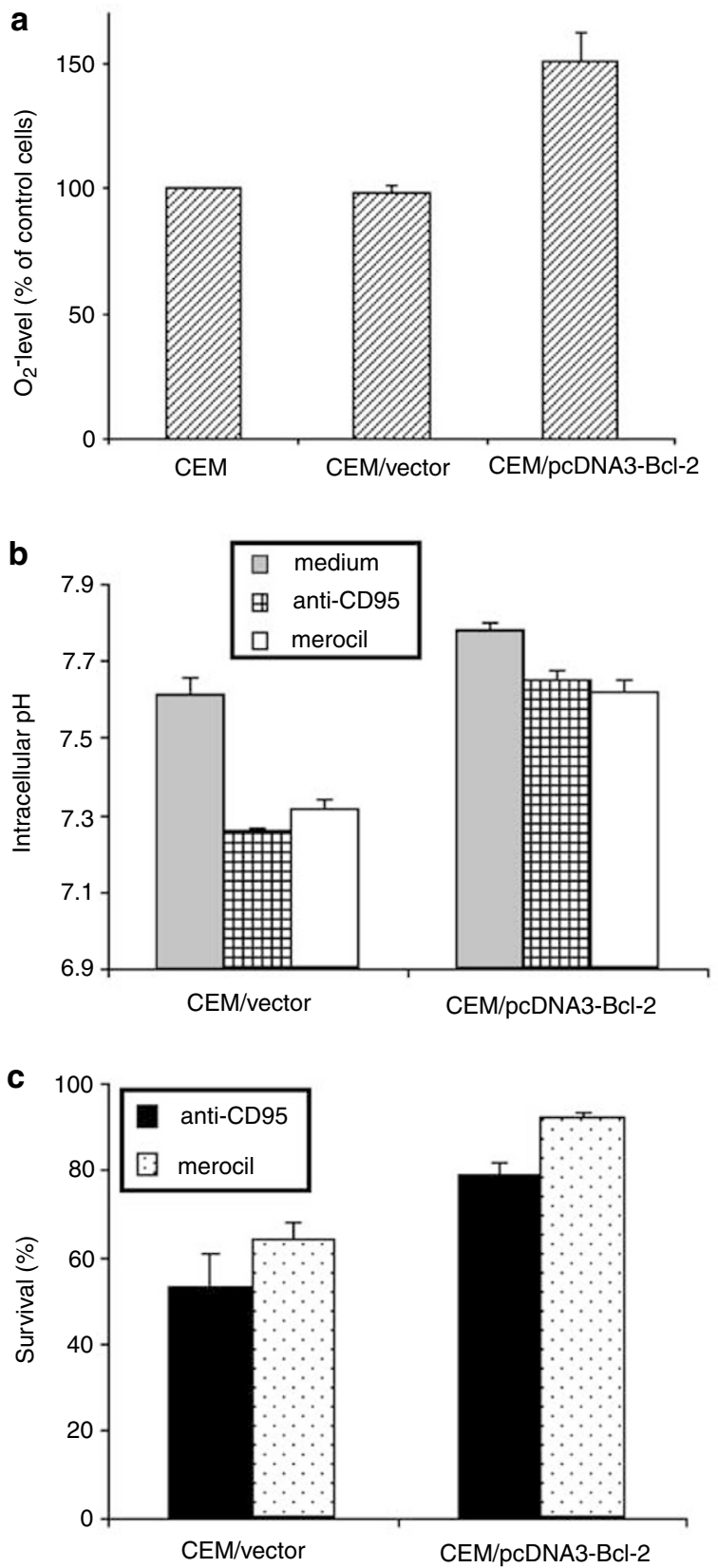

Figure 9 Transient transfection with pcDNA3-Bcl-2 increases intracellular $\mathrm{O}_{2}^{-}$ and inhibits apoptotic acidification and cell death. (a) Transient transfection of CEM cells with pcDNA3-Bcl-2 was performed as described Material and Methods. The intracellular level of $\mathrm{O}_{2}^{-}$was determined in the $\mathrm{CEM}$ or $\mathrm{CEM} /$ vector or CEM/pcDNA3-Bcl-2 cells by the lucigenin-based chemiluminescence assay as described Material and Methods. Data are shown as percentage difference in intracellular $\mathrm{O}_{2}^{-}$relative to the untransfected cells (set as $100 \%$ ). Mean \pm S.D. of three independent observations is shown. (b) In all, $1 \times 10^{6} \mathrm{CEM} / v e c t o r$ or CEM/ pcDNA3-Bcl-2 cells were incubated with $50 \mu \mathrm{g} / \mathrm{ml}$ of merocil or $0.25 \mu \mathrm{g} / \mathrm{ml}$ of antiCD95 for $4 \mathrm{~h}$ (cytosolic $\mathrm{pH}$ ) or (c) $18 \mathrm{~h}$ for cell survival. Cytosolic $\mathrm{pH}$ was determined by BCECF-AM loading and cell survival was assayed by the $\beta$-Gal survival assay as described in Material and Methods

factors. ${ }^{31,32}$ On the contrary, the inhibitory effect of Bcl-2 on CD95-induced apoptosis appears to be mediated by its ability to inhibit caspase 8 activation and caspase 8-dependent cytosolic acidification, thereby creating a nonpermissive 
intracellular milieu for death execution. In the context of Type II cells, such as CEM, this could simply be a function of Bcl-2mediated inhibition of the release of mitochondrial proapoptotic factors required for the amplification of the caspase cascade. However, an alternative hypothesis could be that Bcl-2 has an inhibitory effect on caspase 8 activation, independent of the mitochondria. This would imply that cells that retain a completely functional $\mathrm{Bcl}-2$ with respect to death signaling downstream of the mitochondria, could still be tailored to a conducive intracellular milieu for caspase activation in the complete absence of mitochondrial involvement. To this end, we have recently demonstrated that a permissive intracellular milieu is a function of a decrease in intracellular $\mathrm{O}_{2}^{-}$concentration and cytosolic acidification. ${ }^{5,10,14,15}$ An increase in intracellular $\mathrm{O}_{2}^{-}$inhibits apoptotic signaling irrespective of the trigger, ${ }^{15,16}$ and pharmacological or molecular inhibition of the intracellular $\mathrm{O}_{2}^{-}$producing oxidase complex (NADPH oxidase) results in an increase in cell sensitivity to apoptosis via a direct or indirect effect on caspase activation pathways. ${ }^{14,15}$ Intrigued by these findings, here we set out to investigate if the death inhibitory activity of Bcl-2 could be a function of a pro-oxidant intracellular milieu (increase in the constitutive level of $\mathrm{O}_{2}^{-}$), and if so could the sensitivity to apoptosis be restored by favorably tailoring the intracellular environment of $\mathrm{CEM} / \mathrm{Bcl}-2$ cells. Indeed, not only do we provide evidence that the intracellular $\mathrm{O}_{2}^{-}$concentration is elevated in $\mathrm{CEM} / \mathrm{Bcl}-2$ cells, but in order to further link this to the inhibitory effect of Bcl-2 on caspase activation, we demonstrate here that decreasing intracellular $\mathrm{O}_{2}^{-}$facilitates caspase 8 activity and caspase 8-dependent acidification during apoptosis in $\mathrm{CEM} / \mathrm{Bcl}-2$ cells. The increase in intracellular $\mathrm{O}_{2}^{-}$in $\mathrm{CEM} / \mathrm{Bcl}-2$ cells compared to the $\mathrm{CEM} /$ $\mathrm{Neo}$ cells is in agreement with our earlier findings that an increase in intracellular $\mathrm{O}_{2}^{-}$level is sufficient to induce inhibition of caspase activity and cell death. ${ }^{5,14-16,23}$ In order to be convinced that our results, indeed, were a function of targeted decrease in the intracellular level of $\mathrm{O}_{2}^{-}$, we used a pharmacological inhibitor of the NADPH oxidase (DPI) and cells transfected with the dominant-negative form of Rac 1 (RacN17). DPI is a widely used inhibitor of $\mathrm{O}_{2}^{-}$production, and we have recently shown that the expression of RacN17 in tumor cells results in the inhibition of $\mathrm{O}_{2}^{-}$production and increase in sensitivity to apoptosis. ${ }^{14}$ Although the small GTPbinding protein Rac 1 is involved in functions other than the activation of NADPH oxidase, such as JNK activation and actin polymerization, in our recent report using targeted mutagenesis of Rac 1, we demonstrated that only the NADPH oxidase-interacting residues conferred resistance to apoptosis. ${ }^{14}$ In addition, our data with DDC, an inhibitor of $\mathrm{Cu} / \mathrm{Zn}$ SOD, provide evidence to support that the increase in sensitivity of CEM/Bcl-2/RacN17 cells to apoptosis was linked to intracellular $\mathrm{O}_{2}^{-}$concentration; maintaining a higher steadystate level of $\mathrm{O}_{2}^{-}$in the presence of RacN17 completely reverted the increase in sensitivity and the drop in $\mathrm{pH}$ observed upon anti-CD95 ligation. In addition, a further proof linking Bcl-2 overexpression to the increase in the constitutive level of $\mathrm{O}_{2}^{-}$is provided by our results, demonstrating a significant increase in intracellular steady-state level of $\mathrm{O}_{2}^{-}$ upon transient transfection of CEM cells with pcDNA3-Bcl-2 (Figure 9).
An easy explanation for the enhanced sensitivity of CEM/ Bcl-2 cells upon decreasing intracellular $\mathrm{O}_{2}^{-}$could be that the mitochondrial protective ability of $\mathrm{Bcl}-2$ was compromised in CEM/Bcl-2/DPI or CEM/Bcl-2/RacN17 cells following antiCD95 or drug-induced apoptosis. This would simply result in mitochondrial $\mathrm{H}_{2} \mathrm{O}_{2}$ production (upon merocil treatment), release of Cyt $c$, assembly of the apoptosome, and caspase 9-driven activation of the caspase cascade. Interestingly, the increase in sensitivity of CEM/Bcl-2 cells upon decreasing intracellular $\mathrm{O}_{2}^{-}$did not involve the mitochondrial death pathway, as there was no detectable Cyt $c$ release or drop in mitochondrial $\Delta \psi_{\mathrm{m}}$ in CEM/Bcl-2/DPI cells upon CD95 ligation. Further evidence to support the absence of mitochondrial signaling in CEM/Bcl-2/DPI cells was the inability of caspase 9 inhibitor (LEHD-fmk) to block death signaling in $\mathrm{CEM} / \mathrm{Bcl}-2 / \mathrm{DPI}$ cells, while the same inhibitor significantly blocked death in the mitochondria-dependent CEM/Neo cells (Figures $5 \mathrm{~b}$ and $6 \mathrm{~d}$ ). Although one could question the absolute specificity of the tetrapeptide caspase inhibitor(s), data showing differences in the responses between $\mathrm{CEM} / \mathrm{Bcl}-2 /$ DPI or CEM/Bcl-2/RacN17 cells and CEM/Neo or CEM/Neo/ piRES cells to the LEHD-fmk tetrapeptide are in favor of some specificity. Furthermore, the absence of caspase 9 involvement is also supported by the lack of LEHDase activity in CEM/Bcl-2/DPI cells upon merocil treatment, while DEVDase and LETDase activities were significantly increased. What is of interest is that the decrease in intracellular $\mathrm{O}_{2}^{-}$sensitized $\mathrm{CEM} / \mathrm{Bcl}-2$ cells to merocil-induced apoptosis by switching from $\mathrm{H}_{2} \mathrm{O}_{2}$-dependent to caspase 8-dependent cytosolic acidification, independent of the mitochondria. These data clearly indicate that the increase in caspase 8 activation and sensitivity of CEM/Bcl-2/DPI cells to apoptosis was not a function of mitochondrial-dependent caspase activation and provides an alternative mechanism for the inhibitory effect of $\mathrm{Bcl}-2$ on caspase 8 activation. Hence, in addition to its inhibitory effect on mitochondrial death pathway, overexpression of $\mathrm{Bcl}-2$ could inhibit death signaling by creating an intracellular milieu nonpermissive for caspase 8 activation, that is, an increase in intracellular $\mathrm{O}_{2}^{-}$.

Collectively, these findings provide further support to our earlier reports that a slight increase in intracellular $\mathrm{O}_{2}^{-}$ is inhibitory to apoptotic signaling, irrespective of the trigger. ${ }^{14-16,23}$ Thus, in the presence of a conducive intracellular milieu for caspase 8 activity (low intracellular $\mathrm{O}_{2}^{-}$), a mitochondria-dependent death signal could be diverted to a mitochondria-independent signal in the same cell line. These data support the recent observation that existence of cells with restricted ability to engage mitochondria-dependent or mitochondria-independent pathways upon CD95-induced apoptosis may not be entirely true, and a switch from one to the other could occur in the same cell, provided the conditions are optimal. $^{33,34}$ This bypass effect is a direct outcome of increased caspase 8 activity that can trigger cytosolic acidification and amplification of the caspase cascade. Furthermore, contrary to the general notion that the mitochondrial pathway is required for drug-induced apoptosis, our data demonstrate that an increase in caspase 8 activity can effectively drive the execution signal in the complete absence of mitochondrial involvement, thereby converting a mitochondrial death signal into a mitochondria-independent signal 
during drug-induced apoptosis. These findings could have tremendous implications for designing therapies to enhance or divert apoptotic signaling in hematopoietic and other malignancies, where overexpression of the oncoprotein Bcl2 limits the efficacy of chemotherapy regimens. Thus, the probable effector mechanism(s) for increasing the apoptotic sensitivity of cancer cells could be to manipulate intracellular $\mathrm{O}_{2}^{-}$and facilitate cytosolic acidification, thereby creating an environment permissive for efficient apoptotic execution and enhancing the efficacy of chemotherapy. The exact mechanism involved in the inhibition of caspase 8 activity by the slightly raised intracellular level of $\mathrm{O}_{2}^{-}$still remains to be elucidated and is the focus of our ongoing investigations.

\section{Materials and Methods}

\section{Cell lines}

CEM human leukemia cells stably transfected with the control vector (CEM/Neo) or Bcl-2 (CEM/Bcl-2) were generously provided by Dr Roberta A Gottlieb (Scripps Cancer Center, La Jolla, CA, USA). Cells were maintained in RPMI 1640 supplemented with $5 \%$ fetal bovine serum and $20 \mu \mathrm{g} / \mathrm{ml}$ of $\mathrm{G} 418$ in a $37^{\circ} \mathrm{C}$ incubator with $5 \% \mathrm{CO}_{2}$. The expression of $\mathrm{Bcl}-$ 2 was confirmed by Western blot analysis using a primary anti-Bcl2 antibody (clone Bcl-2/100 at 1: 1000 dil.; BD Pharmingen, San Diego, CA, USA) and a secondary HRP-conjugated anti-mouse IgG (1 : 5000 dilution; Pierce, Rackford, IL, USA). Apoptosis was induced by exposure of cells $\left(1 \times 10^{6} / \mathrm{ml}\right.$ ) to $0.25 \mu \mathrm{g} / \mathrm{ml}$ anti-CD95 lgM (clone $\mathrm{CH} 11$, Upstate Biotech., Lake Placid, NY, USA) or the anticancer agent merocil ${ }^{35}(50 \mu \mathrm{g} / \mathrm{ml})$ for 4-18 h. Cell survival was determined by the MTT assay and apoptosis was assessed by propidium iodide (PI) staining for cell cycle (percentage of sub-G1 for apoptosis) as described previously. ${ }^{35}$

\section{Determination of caspases 3, 8, and 9 activities}

Caspases 3, 8, and 9 activities were assayed by using AFC-conjugated substrates supplied by Biorad Laboratories (Hercules, CA, USA). Cells $\left(1 \times 10^{6} \mathrm{cells} / \mathrm{ml}\right)$ were exposed to merocil $(50 \mu \mathrm{g} / \mathrm{ml})$ or anti-CD95 $(0.25 \mu \mathrm{g} / \mathrm{ml})$ for $4-18 \mathrm{~h}$, washed twice with $1 \times$ PBS, resuspended in $50 \mu \mathrm{l}$ of chilled cell lysis buffer (provided by the supplier) and incubated on ice for $10 \mathrm{~min} 50 \mu \mathrm{l}$ of $2 \times$ reaction buffer ( $10 \mathrm{mM}$ HEPES, $2 \mathrm{mM}$ EDTA, $10 \mathrm{mM}$ $\mathrm{KCl}, 1.5 \mathrm{mM} \mathrm{MgCl}_{2}, 10 \mathrm{mM} \mathrm{DTT}$ ) and $6 \mu \mathrm{l}$ of the fluorogenic caspasespecific substrates (DEVD-AFC for caspase 3, LETD-AFC for caspase 8, and LEHD-AFC for caspase 9) were added to each sample and incubated at $37^{\circ} \mathrm{C}$ for $30 \mathrm{~min}$. Protease activity was determined by measuring the relative fluorescence intensity at $505 \mathrm{~nm}$ following excitation at $400 \mathrm{~nm}$ using a spectrofluorimeter (TECAN Spectrofluor Plus, Austria). Results are shown as fold increase ( $x$ increase) in activity relative to the enzymatic activity obtained from untreated control cells $(1 \times)$. Activation of caspase 8 was also assessed by Western blot analysis for Bid cleavage using a rabbit polyclonal anti-Bid IgG (Biovision Research Products, Paolo Alto, CA, USA) that recognizes the $22 \mathrm{kDa}$ full-length Bid or a polyclonal anti-Bid (Cell Signaling, Beverley, MA, USA) that picks up the $15 \mathrm{kDa}$ truncated Bid. To do so, lysates from $3 \times 10^{6}$ cells (CEM/Neo, CEM/Neo/ $\mathrm{DPI}, \mathrm{CEM} / \mathrm{Bcl}-2$, and CEM/Bcl-2/DPI) exposed to anti-CD95 for $6 \mathrm{~h}$ were subjected to $12 \%$ SDS-PAGE, transferred to polyvinylidene diflouride (PVDF), and incubated with anti-Bid (1:2000 dil.) followed by the antirabbit IgG-HRP. Membranes were then exposed to Super Signal Substrate Western Blotting Kit (Pierce, Rockford, IL, USA) for the detection of the $22 \mathrm{kDa}$ Bid or the $15 \mathrm{kDa}$ truncated Bid (t-Bid).

\section{Measurement of pHi with BCECF}

pHi was measured by loading cells with the fluorescent $\mathrm{pH}$ indicator $2^{\prime}, 7^{\prime}$ bis(2-carboxyethyl)-5,6-carboxyfluorescein (BCECF-AM; Sigma, St Louis, MO, USA) as described elsewhere. ${ }^{8,36}$ Briefly, cells $\left(1 \times 10^{6}\right)$ were washed once with HBSS (Sigma, St Louis, MO, USA), resuspended in $0.1 \mathrm{ml}$ of HBSS, and loaded with $10 \mu \mathrm{l}$ of $1 \mathrm{mM} \mathrm{BCECF}$ at $37^{\circ} \mathrm{C}$ for $30 \mathrm{~min}$ in the dark. The cell pellet was then washed once with HBSS and kept on ice. Immediately before flow cytometry analysis, the cell pellet was resuspended in $0.5 \mathrm{ml}$ of HBSS and analyzed using a Coulter EPICS Elite ESP (Coulter, Hialeah, FL, USA) flow cytometer with the excitation set at $488 \mathrm{~nm}$. A minimum of 10000 events were analyzed and the ratio of BCECF fluorescence at 525 and $610 \mathrm{~nm}$ was used to obtain $\mathrm{pHi}$ from a pH calibration curve. In order to generate a pH calibration curve, cells were loaded with BCECF as above, washed once with HBSS, and then resuspended in high $\mathrm{K}^{+}$buffer $\left(135 \mathrm{mM} \mathrm{KH}_{2} \mathrm{PO}_{4}, 20 \mathrm{mM} \mathrm{NaCl}\right.$, and $110 \mathrm{mM} \mathrm{K}_{2} \mathrm{HPO}_{4}$, and $20 \mathrm{mM} \mathrm{NaCl}$ with a range of $\mathrm{pH}$ between 6.0 and 8.0). Immediately before flow cytometry, cells were loaded with $10 \mu \mathrm{M}$ nigericin (1 $\mathrm{mM}$ stock in absolute alcohol, Sigma, St Louis, MO, USA), and fluorescence ratio measurements $(525 \mathrm{~nm} / 610 \mathrm{~nm})$ of cells in nigericincontaining buffers of a range of $\mathrm{pH}$ were then used to relate histogram channel numbers to $\mathrm{pHi}$. To evaluate the effect of scavenging intracellular $\mathrm{H}_{2} \mathrm{O}_{2}$ on $\mathrm{pHi}$, cells were incubated with catalase $(1000 \mathrm{U} / \mathrm{ml})$ for $1 \mathrm{~h}$ before treatment with merocil or anti-CD95.

\section{Flow cytometric analysis of intracellular $\mathrm{H}_{2} \mathrm{O}_{2}$ concentration}

Intracellular concentration of $\mathrm{H}_{2} \mathrm{O}_{2}$ was determined by staining with $\mathrm{DCFH}$ DA (Molecular Probes, Eugene, OR, USA), which is oxidized to DCF by $\mathrm{H}_{2} \mathrm{O}_{2}$. Cells were exposed to $0.25 \mu \mathrm{g} / \mathrm{ml}$ of anti-CD95 or $50 \mu \mathrm{g} / \mathrm{ml}$ of merocil for $2-8 \mathrm{~h}$, loaded with $5 \mu \mathrm{M} \mathrm{DCFH}-\mathrm{DA}$ at $37^{\circ} \mathrm{C}$ for $15 \mathrm{~min}$, and analyzed by flow cytometry (Coulter EPICS Elite ESP) using an excitation wavelength of $488 \mathrm{~nm}$.

\section{Transient transfection with RacN17or Bcl-2}

Transient transfections of $\mathrm{CEM} / \mathrm{Neo}$ or $\mathrm{CEM} / \mathrm{Bcl}-2$ cells were performed using the SuperFect Transfection Reagents from QIAGEN Gmbh (Germany). Briefly, $3 \mu \mathrm{g}$ of the pIRES (empty vector) or pIRESRacN17 or pcDNA3-Bcl-2 and $2 \mu \mathrm{g}$ of the $\mathrm{pCMV} \beta$ plasmid encoding for the $\beta$-gal protein were added to $20 \mu \mathrm{l}$ of the SuperFect Transfection Reagent and transfection was carried out as recommended by the vendor. At $48 \mathrm{~h}$ after transfection, cell lysates were collected and expressions of the transiently expressed RacN17 mutant protein or Bcl-2 protein were detected by Western blotting using $2 \mu \mathrm{g} / \mathrm{ml}$ of a monoclonal anti-human myc epitope antibody or (Boehringer Mannheim, Indianapolis, IN, USA) or anti-Bcl-2 (clone Bcl-2/100; BD Pharmingen, San Diego, CA, USA).

\section{$\beta$-Gal survival assay}

Survival of transiently transfected cells was assessed by the $\beta$-gal survival assay as described elsewhere. ${ }^{14}$ Following triggering of apoptosis with anti-CD95 or merocil, \% survival was calculated as: ( $\beta$-gal activity $/ \mu \mathrm{g}$ of protein of transfected cells incubated with the apoptotic trigger $) /(\beta$-gal activity $/ \mu \mathrm{g}$ of protein of transfected cells incubated without the trigger)). $\beta$-gal activity was measured using the Galacto-Star mammalian reporter Kit (TROPIX, Bedford, MA, USA). Protein concentration was determined using the Coomasie Plus protein assay reagent from Pierce (Pierce Chemical Company, Rockford, IL, USA). 


\section{Intracellular $\mathrm{O}_{\mathbf{2}}^{-}$measurement}

A lucigenin-based chemiluminescence assay was used for measuring intracellular $\mathrm{O}_{2}^{-}$as previously described. ${ }^{16}$ Chemiluminescence was monitored for $60 \mathrm{~s}$ using a Berthold Sirius Luminometer (Berthold detection systems $\mathrm{GmbH}$, Bleichstrabe/Pforzheim/Germany). Lucigenin is a widely used chemiluminescent detector of intracellular $\mathrm{O}_{2}^{-}$in biological systems. ${ }^{37}$ Moreover, despite some reports questioning its validity, ${ }^{38}$ the work of $\mathrm{Li}$ et al. ${ }^{39}$ has elegantly demonstrated that lucigenin is a reliable assay for detecting $\mathrm{O}_{2}^{-}$production by enzymatic and cellular sources. In order to assess the effect of NADPH oxidase inhibitor DPI on intracellular $\mathrm{O}_{2}^{-}$levels, cells were preincubated with $2.5 \mu \mathrm{M} \mathrm{DPI}$ for $1 \mathrm{~h}$ before assaying for intracellular $\mathrm{O}_{2}^{-}$. Data are shown as relative light units $/ \mu \mathrm{g}$ of protein $(\mathrm{RLU} / \mu \mathrm{g}$ protein) \pm S.D. from three to six independent measurements. Protein concentration was determined using the Coomasie Plus protein assay reagent from Pierce (Pierce Chemical Company, Rockford, IL, USA).

\section{Detection of cytosolic Cyt c}

Cytosolic translocation of Cyt $c$ was assessed by Western blot analysis of cytosolic extract from $30 \times 10^{6}$ cells as described previously. ${ }^{35}$ In total, $60 \mu \mathrm{g}$ of protein was subjected to $12 \%$ SDS-PAGE followed by transfer to PVDF membrane using a Trans-blot SD semidry system (Bio-Rad Laboratories, Hercules, CA, USA). Membrane was then probed with 1 : 1000 dil. of anti-Cyt $c$ (7H8.2C12; Pharmingen, San Diego, CA, USA) followed by the secondary anti-mouse lgG-HRP, and the signal was detected by the Super Signal Substrate Western Blotting Kit (Pierce, Rockford, IL, USA).

\section{Determination of mitochondrial $\Delta \Psi_{m}$ by flow cytometry}

Potential-sensitive probe $3,3^{\prime}$ dihexyloxacarbocyanine iodide $\left(\mathrm{DiOC}_{6}\right)$ was used to measure mitochondrial $\Delta \psi_{\mathrm{m}}$ as described elsewhere. ${ }^{35}$ Briefly, $1 \times 10^{6}$ cells were incubated with $3,3^{\prime} \mathrm{DiOC}_{6}(40 \mathrm{nM})$ for $15 \mathrm{~min}$ at $37^{\circ} \mathrm{C}$. Cells were washed twice with $1 \times$ PBS and immediately analyzed in Epic Profile flow cytometer with excitation set at $488 \mathrm{~nm}$. Data were analyzed for 20000 events using the WinMDI software.

\section{Acknowledgements}

We thank Dr Roberta Gottlieb, Scripps, La Jolla, CA, USA for the generous gift of the CEM/Neo and CEM/Bcl-2 cells, and Dr Stanley Korsmeyer, Boston, MA, USA for the generously providing the pcDNA3-Bcl-2 plasmid. We also wish to acknowledge Kartini Iskander and Sun Yu for technical assistance. This work was supported by Grants R-185-000-019-213 and R-185-000-032-213 to SP, and R-364-000-013-213 to M-VC from the NMRC, Singapore and a Grant R-185-000-048-305 to SP and M-VC form the BMRC, Singapore.

\section{References}

1. Wyllie AH (1981) Cell death: a new classification separating apoptosis from necrosis. In Cell Death in Biology and Pathology Bowen ID, Lockshin RA (eds) London: Chapman \& Hall, pp. 9-34

2. Kroemer $G$ and Reed JC (2000) Mitochondrial control of cell death. Nat. Med. 6: $513-519$
3. Scaffidi C, Fulda S, Srinivasan A, Friesen C, Li F, Tomaselli KJ, Debatin KM, Krammer PH and Peter ME (1998) Two CD95 (APO-1/Fas) signaling pathways. EMBO J. 17: 1675-1687

4. Gottlieb RA, Nordberg J, Skowronski E and Babior BM (1996) Apoptosis induced in Jurkat cells by several agents is preceded by intracellular acidification. Proc. Natl. Acad. Sci. USA 93: 654-658

5. Pervaiz S and Clement MV (2002) A permissive apoptotic environment: function of a decrease in intracellular superoxide anion and cytosolic acidification. Biochem. Biophys. Res. Commun. 290: 1145-1150

6. Matsuyama S and Reed JC (2000) Mitochondria-dependent apoptosis and cellular pH regulation. Cell Death Differ. 7: 1155-1165

7. Matsuyama S, Llopis J, Deveraux QL, Tsien RY and Reed JC (2000) Changes in intramitochondrial and cytosolic $\mathrm{pH}$ : early events that modulate caspase activation during apoptosis. Nat. Cell Biol. 2: 318-325

8. Hirpara JL, Clement MV and Pervaiz S (2001) Intracellular acidification triggered by mitochondrial-derived hydrogen peroxide is an effector mechanism for drug-induced apoptosis in tumor cells. J. Biol. Chem. 276: 514-521

9. Liu D, Martino G, Thangaraju M, Sharma M, Halwani F, Shen SH, Patel YC and Srikant CB (2000) Caspase-8-mediated intracellular acidification precedes mitochondrial dysfunction in somatostatin-induced apoptosis. J. Biol. Chem. 275: 9244-9250

10. Clement MV, Ponton A and Pervaiz S (1998) Apoptosis induced by hydrogen peroxide is mediated by decreased superoxide anion concentration and reduction of intracellular milieu. FEBS Lett. 440: 13-18

11. Adachi S, Cross AR, Babior BM and Gottlieb RA (1997) Bcl-2 and the outer mitochondrial membrane in the inactivation of cytochrome $c$ during Fasmediated apoptosis. J. Biol. Chem. 272: 21878-21882

12. Meisenholder GW, Martin SJ, Green DR, Nordberg J, Babior BM and Gottlieb RA (1996) Events in apoptosis. Acidification is downstream of protease activation and BCL-2 protection. J. Biol. Chem. 271: 16260-16262

13. Thangaraju M, Sharma K, Leber B, Andrews DW, Shen SH and Srikant CB (1999) Regulation of acidification and apoptosis by SHP-1 and Bcl-2. J. Biol. Chem. 274: 29549-29557

14. Pervaiz S, Cao J, Chao OS, Chin YY and Clement MV (2001) Activation of the RacGTPase inhibits apoptosis in human tumor cells. Oncogene 20: 6263-6268

15. Pervaiz S, Ramalingam JK, Hirpara JL and Clement MV (1999) Superoxide anion inhibits drug-induced tumor cell death. FEBS Lett. 459: 343-348

16. Clement MV and Stamenkovic I (1996) Superoxide anion is a natural inhibitor of FAS-mediated cell death. EMBO J. 15: 216-225

17. Thangaraju M, Sharma K, Liu D, Shen SH and Srikant CB (1999) Interdependent regulation of intracellular acidification and SHP-1 in apoptosis. Cancer Res. 59: 1649-1654

18. Engels IH, Stepczynska A, Stroh C, Lauber K, Berg C, Schwenzer R, Wajant H, Janicke RU, Porter AG, Belka C, Gregor M, Schulze-Osthoff K and Wesselborg W (2001) Caspase-8/FLICE functions as an executioner caspase in anticancer drug-induced apoptosis. Oncogene 19: 4563-4573

19. Fulda S, Meyer E, Friesen C, Susin SA, Kroemer G and Debatin KM (2001) Cell type specific involvement of death receptor and mitochondrial pathways in drug-induced apoptosis. Oncogene 20: 1063-1075

20. Korsmeyer SJ, Yin X-M, Oltvai Z, Veis-Novack DJ and Linette GP (1995) Reactive oxygen species and regulation of cell death by the $\mathrm{Bcl}-2$ gene family. Biochem. Biophys. Acta 1271: 63-66

21. Steinman HM (1995) The Bcl-2 oncoprotein functions as a pro-oxidant. J. Biol. Chem. 270: 3487-3490

22. Voehringer DW and Meyn RE (2000) Redox aspects of Bcl-2 function. Antioxid. Redox Signal 2: 537-550

23. Clement MV and Pervaiz S (1999) Reactive oxygen intermediates regulate cellular response to apoptotic stimuli: an hypothesis. Free Radic. Res. 30: 247-252

24. Armstrong JS and Jones DP (2002) Glutathione depletion enforces the mitochondrial permeability transition and causes cell death in $\mathrm{HL} 60$ cells that overexpress Bcl-2. FASEB J. 10: 1263-1265

25. Babior BM (1999) NADPH oxidase: an update. Blood 93: 1464-1476

26. Kobayashi T, Tsunawaki S and Seguchi H (2001) Evaluation of the process for superoxide production by NADPH oxidase in human neutrophils: evidence for cytoplasmic origin of superoxide. Redox Rep. 6: 27-36

27. Irani K and Goldschmidt-Clermont PJ (1998) Ras, superoxide and signal transduction. Biochem. Pharmacol. 55: 1339-1346 
28. Irani K, Xia Y, Zweier JL, Sollott SJ, Der CJ, Fearon ER, Sundaresan M, Finkel T and Goldschmidt-Clermont PJ (1997) Mitogenic signaling mediated by oxidants in Ras-transformed fibroblasts. Science 275: 1649-1652

29. Sundaresan M, Yu ZX, Ferrans VJ, Sulciner DJ, Gutkind JS, Irani K Goldschmidt-Clermont PJ and Finkel T (1996) Regulation of reactiveoxygen-species generation in fibroblasts by Rac1. Biochem. J. 318 (Part 2): 379-382

30. Babior BM (2000) The NADPH oxidase of endothelial cells. IUBMB Life 50 $267-269$

31. Hockenbery D, Oltvai ZN, Yin X-M, Milliman CL and Korsmeyer SJ (1993) Bcl-2 functions in an antioxidant pathway to prevent apoptosis. Cell 75: 241-251

32. Nomura K, Imai H, Koumura T, Kobayashi $T$ and Nakagawa $Y(2000)$ Mitochondrial phospholipid hydroperoxide glutathione peroxidase inhibits the release of cytochrome $c$ from mitochondria by suppressing the peroxidation of cardiolipin in hypoglycaemia-induced apoptosis. Biochem. J. 351 (Part 1): 183-193

33. Huang DC, Tschopp J and Strasser A (2000) Bcl-2 does not inhibit cell death induced by the physiological Fas ligand: implications for the existence of type and type II cells. Cell Death Differ. 7: 754-755
34. Huang DC, Hahne M, Schroeter M, Frei K, Fontana A, Villunger A, Newton K, Tschopp J and Strasser A (1999) Activation of Fas by FasL induces apoptosis by a mechanism that cannot be blocked by Bcl-2 or Bcl-x(L). Proc. Natl. Acad. Sci. USA 96: 14871-14876

35. Pervaiz S, Seyed MA, Hirpara JL, Clement MV and Loh KW (1999) Purified photoproducts of merocyanine 540 trigger cytochrome $C$ release and caspase 8-dependent apoptosis in human leukemia and melanoma cells. Blood 93: 4096-4108

36. Musgrove EA and Hedley DW (1990) Measurement of intracellular pH. Methods Cell Biol. 33: 59-69

37. Gyllenhammar H (1987) Lucigenin chemiluminescence in the assessment of neutrophil superoxide production. J. Immunol. Methods 97: 209-220

38. Liochev SI and Fridovich I (1997) Lucigenin luminescence as a measure of intracellular superoxide dismutase activity in Escherichia coli. Proc. Natl. Acad. Sci. USA 94: 2891-2896

39. Li Y, Kuppusamy P, Roubaud V, Zweier JL and Trush MA (1998) Validation of lucigenin (bis- $\mathrm{N}$-methylacridinium) as a chemilumigenic probe for detecting superoxide anion radical production by enzymatic and cellular systems. J. Biol. Chem. 273: 2015-2023 